\title{
Bakteriális infekciók májátültetés után
}

\author{
Nemes Balázs dr. ${ }^{1}$ - Gelley Fanni dr. ${ }^{2}$ - Dabasi Eszter ${ }^{2}$ \\ Gámán György dr. ${ }^{2}$ - Fehérvári Imre dr. ${ }^{2}$ - Görög Dénes dr. ${ }^{2}$ \\ Kóbori László dr. ${ }^{2}$ - Fazakas János dr. ${ }^{2}$ - Vitális Eszter dr. ${ }^{3}$ \\ Doros Attila dr. ${ }^{2}$. Gálffy Zsuzsanna dr. ${ }^{2}$ - Máthé Zoltán dr. ${ }^{2}$
}

\author{
${ }^{1}$ Debreceni Egyetem, Általános Orvostudományi Kar, Sebészeti Intézet, \\ Szervtranszplantációs nem önálló Tanszék, Debrecen \\ ${ }^{2}$ Semmelweis Egyetem, Általános Orvostudományi Kar, \\ Transzplantációs és Sebészeti Klinika, Budapest \\ ${ }^{3}$ Debreceni Egyetem, Általános Orvostudományi Kar, Aneszteziológiai és Intenzívterápiás Tanszék, Debrecen
}

Bevezetés: A szerzők a májátültetést követően kialakult mikrobás fertőzéseket, a mintavételek eredményeit, a multidrug-rezisztencia incidenciáját vizsgálták a hazai betegek körében. Célkitüzés: Tanulmányozták a bakteriális fertőzés kialakulásának kockázati tényezőit, az infekciókhoz kapcsolódó szövődmények előfordulását, lefolyását, és részletes kórokozó-spektrumelemzést végeztek. Módszer: 2003-2012 között májátültetett 408 beteg adatait (281 bakteriológiai tenyésztést) vizsgálták. Eredmények: A 408 beteg közül 70 betegnél (17\%) észleltek klinikai tünetekkel járó fertőzést. A tenyésztési lelet 58 betegnél (14,2\%) pozitív, 12 betegnél $(2,9 \%)$ negatív volt. Hét esetben $(12,1 \%)$ alakult ki cholangitis, 17 esetben $(29,3 \%)$ fordult elő hasűri és 28 esetben $(48,3 \%)$ pulmonalis eredetű fertőzés. Posztoperatív fertőzés gyakrabban lépett fel kezdeti csökkent graftmúködés, akut veseelégtelenség, epeúti szövődmény és hasưri vérzés mellett. Infekció kialakulása esetén az 1, 3 és 5 éves betegtúlélés $70 \%, 56 \%$ és $56 \%$ volt, míg infekció nélkül ez $94 \%, 87 \%, 85 \%$ volt $(\mathrm{p}<0,001)$. A kitenyészett baktériumok 56\%-ánál találtak multidrug-rezisztenciát, viszont nem volt szignifikáns különbség a multidrug-rezisztencia pozitív és negatív baktériummal fertőzött csoportok egyéves betegtúlélése között (70,2\% mindkettő). Következtetések: Az infekciókontroll, a multidrug-rezisztens kórokozók menedzselése a preventív, higiéniai, izolációs elvek kialakítását, betartását, valamint mútéttechnikai, transzfúziós, antibiotikus stratégiák, folyamatok fejlesztését kell, hogy megcélozza, szakmai csapatmunka keretén belül. Orv. Hetil., $2015,156(34), 1366-1382$.

Kulcsszavak: májátültetés, posztoperatív fertőzés, multidrug-rezisztencia, túlélés, szepszis

\section{Bacterial infection after orthotopic liver transplantation}

Introduction: The authors reviewed the prevalence of postoperative infections, the results of bacterium cultures, and the incidence of multidrug resistance in their liver transplanted patients during a period between 2003 and 2012. Aim: The aim of this study was to analyse risk factors and colonisations of bacterial infections. Method: The files of 408 patients (281 bacterium cultures) were reviewed. Results: Of the 408 patients 70 had a postoperative infection (17\%); 58 patients $(14.2 \%)$ had positive and 12 patients $(2.9 \%)$ negative bacterial culture results. Cholangitis was found in 7 cases $(12.1 \%)$, abdominal infection in 17 cases $(29.3 \%)$, and pulmonal infection in 28 cases $(48.3 \%)$. Postoperative infection was more frequent in patients with initial poor graft function, acute renal insufficiency, biliary complication, and in those with intraabdominal bleeding. The 1-, 3- and 5-year cumulative survival of patients who had infection was $70 \%, 56 \%$ and $56 \%$, respectively, whereas the cumulative survival data of patients without infection was $94 \%, 87 \%$ and $85 \%$, respectively $(\mathrm{p}<0.001)$. Multidrug resistance was found in $56 \%$ of the positive cultures, however, the one-year survival was not different in patients who had multidrug resistance positive and negative bacterial infection (both 70.2\%). Conclusions: Infection control must target the management of multidrug resistance microbes through encouraging prevention, hygienic, and isolation rules, improving the operational, transfusion, and antimicrobial policy in a teamwork setting.

Keywords: orthotopic liver transplantation, bacterial infection, multidrug resistance, survival, sepsis

Nemes, B., Gelley, F., Dabasi, E., Gámán, Gy., Fehérvári, I., Görög, D., Kóbori, L., Fazakas, J., Vitális, E., Doros, A., Gálffy, Zs., Máthé, Z. [Bacterial infection after orthotopic liver transplantation]. Orv. Hetil., 2015, 156(34), 13661382 .

(Beérkezett: 2015. április 24.; elfogadva: 2015. június 18.) 


\section{Rövidítések}

$\mathrm{AB}=$ antibiotikum; ARDS $=$ acute respiratory distress syndrome; $\mathrm{BAL}=$ bronchoalveolaris lavage $; \mathrm{BMI}=$ (body mass index $)$ testtömegindex; CIT $=($ cold ischemic time $)$ hideg ischaemiás idő; $\mathrm{CyA}=$ cyclosporin $\mathrm{A} ; \mathrm{DM}=$ diabetes mellitus; $\mathrm{ECD}=($ extended donor criteria $)$ kiterjesztett donorkritériumok; ESBL $=($ extended-spectrum $\beta$-lactamase $)$ széles spektrumú béta-laktamáz; FFP = friss fagyasztott plazma; GGT = gamma-glutamil-transzferáz; GOT = glutaminsav-oxálecetsavtranszamináz (AST); GPT = glutaminsav-piroszőlősav-transzamináz (ALT); HAS = (hepatic artery stenosis) arteria hepatica stenosis; HAT $=$ (hepatic artery thrombosis) arteria hepatica thrombosis; $\mathrm{HBV}=$ hepatitis $\mathrm{B}$-vírus; $\mathrm{HCV}=$ hepatitis C-vírus; HPS = hepatopulmonalis szindróma; HRS = hepatorenalis szindróma; IPF = (initial poor function) kezdeti csökkent graftmúködési zavar; ITO = intenzív terápiás osztály; KNS = koaguláznegatív Staphylococcus; MDR = multidrug-rezisztencia MELD = model for end-stage liver disease; $\mathrm{MMF}=$ mycophenolate mofetil; $\mathrm{MOF}=$ (multiorgan failure) sokszervi elégtelenség; OLT $=($ orthotopic liver transplantation $)$ orthotopicus májátültetés; $\mathrm{PBC}=$ primer biliaris cirrhosis; $\mathrm{PNF}=$ (primary non-function) elsődleges graftmúködési zavar; $\mathrm{PRR}=$ mintázatfelismerô receptorok; PSC = primer szklerotizáló cholangitis; $\mathrm{PVT}=$ (portal vein thrombosis) vena portae thrombosis; $\mathrm{SDD}=$ (selective digestive decontamination) szelektív digestiv dekontamináció; SIRS = (systemic inflammatory response syndrome) szisztémás gyulladásos válaszreakció; $\mathrm{SOD}=$ (selective oropharyngeal decontamination) szelektív oropharyngealis dekontamináció; TAC = tacrolimus; TEG = tromboelasztogram; $\mathrm{UH}=$ ultrahang; UNOS = United Network for Organ Sharing; VCI = vena cava inferior; $\mathrm{VRE}=$ (vancomycin resistant enterococcus) vancomycinrezisztens enterococcus; VVT = vörösvértest; WIT $=($ warm ischemic time $)$ meleg ischaemiás idő

A máj szerzett vagy veleszületett, heveny vagy idült végstádiumú betegségeinek mára elfogadottá vált gyógymódja az orthotopicus májátültetés (OLT). Az elsó sikeres májátültetést Starzl és munkatársai végezték 1963-ban az Amerikai Egyesült Államokban [1]. Európában először 1968-ban, Angliában, Sir Roy Calne vezetésével végeztek orthotopicus májtranszplantációt [2]. Kontinensünkön 2011 decemberéig a májátültetések száma 107071 volt [3]. Magyarországon 1983-ban Szécsény és munkatársai végezték az első ilyen beavatkozást a SOTE I. Sebészeti Klinikáján. A későbbi években ezt további 3 sporadikus eset követte. A szervezett májátültetési program 1995 januárjában, a Perner Ferenc profeszszor által vezetett Transzplantációs és Sebészeti Klinikán kezdődött meg $[4,5,6] .2013$ júliusában hazánk is csatlakozott az Eurotransplanthoz (ET), így a szervezethez tartozó országokból is kaphatnak a magyar betegek szerveket, illetve Magyarországon eltávolított szervek ETtagországban kerülhetnek beültetésre.

Az elmúlt évtizedben a májátültetési program ugrásszerü fejlődésen ment keresztül. A kezdeti rosszabb túlélési adatok hátterében többek között a fertőzések magas aránya és az immunszuppressziós terápia kezdetlegessége állt. Az Egyesült Államokban évente 5-6 ezer végstá- diumú májbeteg kerül transzplantációra, az ötéves betegtúlélés pedig meghaladja a 70\%-ot [7]. A fertőzések aránya az antibiotikus terápia fejlődésével, a megfelelő antimikrobás profilaxis elterjedésével csökkent, de a mai napig számottevő, olykor életet veszélyeztető szövődmény lehet májátültetést követően [7]. Az antibiotikumok elterjedt és sokszor indokolatlan használata mellett viszont világszerte tapasztalt jelenségként megjelentek a multidrug-rezisztens baktériumtörzsek (MDR).

Májátültetést követően, a nagyobb vérveszteséggel járó sebészeti beavatkozással összefüggő tényezők mellett, az immunszuppressziós terápia, az esetleg elhúzódó intenzív osztályos kezelés, széles spektrumú antibiotikumok használata, az operáció idótartama, perioperatív tényezők (epeúti anastomosis szivárgása, a portalis kirekesztésbő́l adódó vénás pangás a belekben, és következményes bakteriális transzlokáció, illetve a jelentős mennyiségű vértranszfúzió) egyaránt rizikófaktort jelentenek az invazív bakteriális fertőzések kialakulására. A májátültetés után észlelt MDR-előfordulásról számos közlemény jelent meg $[7,8]$. Egyes rezisztens baktériumtörzsek jelentős morbiditással és mortalitással járó megbetegedést okoznak [8].

Vizsgálatunk során a májátültetést követően detektált mikrobiológiai mintavételek eredményeit és ezzel összefüggésben az MDR-incidenciát, valamint a kialakult mikrobás fertőzéseket vizsgáltuk a hazai májátültetett betegek körében.

\section{Betegek és módszer}

Retrospektív adatfeldolgozást végeztünk a Semmelweis Egyetem, Transzplantációs és Sebészeti Klinikán 2003. január 1. és 2012. december 31. közötti időszakban végzett májátültetéseket illetően. Ez összesen 408 beteg adatait jelentette. Tanulmányoztuk a bakteriális fertőzés kialakulásának kockázati tényezőit, az infekciókhoz kapcsolódó szövődmények előfordulását, lefolyását. Részletes kórokozó-spektrumelemzést végeztünk a vizsgálat során, hogy feltérképezzük a leglényegesebb törzseket és azok kolonizációjának helyeit. A statisztikai elemzés során a csoportokat összehasonlítottuk a májátültetés során szokásos donor-, recipiens-, perioperatív tényező́k, valamint a posztoperatív események (szövődmények), a beteg- és grafttúlélés szempontjából.

\section{Csoportositás}

Az eredmények jobb bemutatása érdekében csoportokat alkottunk. A csoportalkotásnak két kritériuma volt: a pozitív mikrobás tenyésztési lelet ( $\mathrm{T}=$ tenyésztés) és a fertőzés klinikai tüneteinek megléte ( $\mathrm{I}=$ infekció). Nem minden pozitív tenyésztéshez társult klinikai tünet, így három csoport jött létre $(\mathrm{T}+\mathrm{I}+; \mathrm{T}+\mathrm{I}-; \mathrm{T}-\mathrm{I}+)$, és a negyedik a kontroll (T-I-). 


\section{Definiciók}

Az irodalmi közlések alapján kialakult definíciókat az alábbiakban határoztuk meg.

Bacteriaemia: Klinikai tünetek fennállása és az adott baktérium tenyésztése hemokultúrás mintavételből vagy kanülből, egy lázmenet során [9].

Kolonizáció: Baktériumok általi telepképzés, fertőzés megléte nélkül.

Multidrug-rezisztencia (MDR): Három vagy annál több antibiotikummal szemben egyszerre fennálló rezisztencia [10].

Szelektív digestiv dekontamináció (SDD): Komplex antimikrobiális kezelés, amely az emésztőrendszerben található Gram-negatív baktériumok elleni prevenciót jelenti [11].

Szisztémás szervezeti válaszreakció (SIRS): Infekcióra, illetve nem fertőzéses eredetű (például akut pancreatitis) inzultusra adott diszregulált gyulladásos reakció [12].

Szelektí oropharyngealis dekontamináció (SOD): $\mathrm{Az}$ intenzív osztályokon eltérő kombinációkban alkalmazott antibiotikum-prevenció, a légzőtraktus kolonizációjának, illetve a bacteriaemia megelőzésére elsősorban légúti fertőzések kivédése céljából [13].

Szepszis: A szervezet infekcióra adott szisztémás válaszreakciója. A klinikai kép a szervezet saját reakciója következtében alakul ki, nem a mikrobák direkt hatása miatt. A tünetek közül legalább kettőnek jelen kell lennie: leukocytaszám $>12000 / \mathrm{mm}^{3}$ vagy $<4000 / \mathrm{mm}^{3}$, vagy minimum $10 \%$ éretlen sejt; légzésszám $>20 / \mathrm{min}$ spontán légzésnél, vagy $\mathrm{PaCO}_{2}<31$ torr $(<4,3 \mathrm{kPa})$, tachycardia $(>90 / \mathrm{min})$, hömérséklet $>38^{\circ} \mathrm{C}$ vagy $<36{ }^{\circ} \mathrm{C}$, diasztolés vérnyomás $<60 \mathrm{Hgmm}$, szívfrekvencia $>90 /$ perc [12].

\section{Statisztikai feldolgozás}

A statisztikai elemzésnél a folytonos adatokat átlagértékben (standard deviációban), a kategorikus változókat abszolút értékben és százalékban adtuk meg. Egyvariációs összehasonlítások esetén a folytonos adatokat a populáció homogenitásának vizsgálata után (Levene-teszt) kétmintás t-próbával, illetve Mann-Whitney-féle U-teszttel, a kategorikus adatokat $\chi^{2}$-próbával vizsgáltuk. A túlélést Kaplan-Meier-metodikával vizsgáltuk. Az eredményeket valamennyi statisztikai próbánál akkor tekintettük szignifikánsnak, ha a $\mathrm{p}<0,05$ volt.

\section{Eredmények}

\section{A csoportositás alapján kialakult betegcsoportok}

A 408 betegnél 281, posztoperatív időszakban vett tenyésztés eredményét vizsgáltuk meg. Pozitívnak tekintettük a tenyésztési leletet, ha bármilyen mikroba kimutatható volt szignifikáns, azaz legalább $10^{4}$ csíraszámban. A pozitív tenyésztések alapján két csoportot alkottunk.
Az egyik csoportba kerültek azok a betegek, akiknél a pozitív tenyésztési lelet mellett a fertőzés klinikai tünetei is kialakultak ( $\mathrm{T}=$ tenyésztés, $\mathrm{I}=$ infekció, $\mathrm{T}+\mathrm{I}+$ ). Posztoperatív fertőzés alatt az operációt követő kórházi bennfekvés során szerzett és klinikai tünetekkel járó fertőzést értettük. A másik csoportba a pozitív tenyésztési lelettel rendelkező, de klinikai tüneteket nem mutató esetek kerültek (T+I-). A vizsgált 281 mintából 190 esetben (68\%) találtunk pozitív tenyésztési leletet.

A bakteriális fertőzés jelenlétét a leírt és diagnosztizált klinikai tünetek és diagnózisok (pneumonia, cholangitis, cystitis-uroszepszis), laborleletek, láz, a megkezdett antibiotikus kezelés alapján definiáltuk. Miután voltak olyan betegek is, akiknél jelen voltak ugyan a fertőzés klinikai tünetei, de a tenyésztési leletek negatívak voltak (T-I+), megvizsgáltuk azt is, hogy azoknál a betegeknél, akiknél kialakult fertőzés, milyen arányban volt detektálható pozitív tenyésztési eredmény. A fertőzésben szenvedő betegeket két csoportra osztottuk: $\mathrm{T}+\mathrm{I}+, \mathrm{T}-\mathrm{I}+$. Az utóbbi esetben a fertőzés klinikai tünetei mellett negatívak voltak a - jellemzően többször ismételt - tenyésztési leletek.

A vizsgált 408 beteg közül összesen 70 betegnél (17\%) észleltünk klinikai tünetekkel járó fertőzést, közülük 58 betegnek volt pozitív tenyésztési lelete (14,2\%), ebből adódóan 12 olyan eset is volt $(2,9 \%)$, amikor a kialakult fertőzés ellenére minden tenyésztési lelet negatív maradt. Másképpen fogalmazva: a 70 beteget alapul véve, akiknél klinikai tünetekkel járó fertőzés zajlott, 58-nál (83\%) a tenyésztési leletek között volt pozitív eredmény, 12 betegnél nem (17\%).

A csoportokban kutattuk a szepszis előfordulási gyakoriságát, továbbá azt, hogy a kialakult szepszis során hány beteget vesztettünk el. Célunk volt részletesen megvizsgálni, hogy a pozitív tenyésztési lelet előre jelzi-e a szepszis kialakulását, van-e prediktív értéke. A bakteriális tenyésztések forrásait, illetve spektrumát részletesen elemeztük. A posztoperatív időszakban vett tenyésztések alapján vizsgáltuk a baktériumtörzseket, Gram-festés (pozitív, negatív, kevert fertőzés) szempontjából. A pozitív tenyésztési lelettel rendelkező betegek esetén megfigyeltük a multidrug-rezisztencia (MDR) megjelenési gyakoriságát. Választ vártunk arra a kérdésre, hogy az MDR milyen arányban fordul elő az általunk vizsgált csoportokban, és az előfordulási gyakorisága hogyan alakult az évek során.

Az egyes csoportok közötti összehasonlítást az 1-3. táblázatok mutatják be. Az 1. táblázat a májátültetésre váró recipiensek indikációit hasonlítja össze, külön-külön, pozitív tenyésztési eredmény (1.a) táblázat), illetve pozitív klinikai tünetek esetén (1. b) táblázat). Szignifikáns eltérés nem volt, tehát az összehasonlított csoportok az indikációk szerint homogénnek tekinthetők. A 2. és 3. táblázat a donor és recipiens demográfiai adatokat mutatja be pozitív tenyésztési lelet esetén (2. táblázat) és pozitív klinikai tünetek (3. táblázat) esetén. A donorok demográfiai adatai tekintetében a T+I+ és a T-I+ csoport között nem volt szignifikáns különbség (nem, életkor, 
1. táblázat | A májátültetés indikációja a vizsgált csoportokban

a) Pozitív tenyésztés esetén

\begin{tabular}{lccl}
\hline Indikációk & $\begin{array}{l}\mathrm{T}+/ \mathrm{I}+ \\
\mathrm{N}=58)\end{array}$ & $\begin{array}{l}\mathrm{T}+/ \mathrm{I}- \\
(\mathrm{N}=132)\end{array}$ & $\mathrm{p}$ \\
\hline Autoimmun & $\mathrm{l}(1,8 \%)$ & $5(3,8 \%)$ & $\mathrm{NS}$ \\
Alkohol & $10(17,2 \%)$ & $18(13,6 \%)$ & $\mathrm{NS}$ \\
HBV & $2(3,4 \%)$ & $8(6 \%)$ & $\mathrm{NS}$ \\
HCV & $12(20,7 \%)$ & $52(39,4 \%)$ & $\mathrm{NS}$ \\
PBC & $1(1,8 \%)$ & $5(3,8 \%)$ & $\mathrm{NS}$ \\
PSC & $4(6,9 \%)$ & $17(12,9 \%)$ & $\mathrm{NS}$ \\
Egyéb & $28(48,3 \%)$ & $27(20,5 \%)$ & $\mathrm{NS}$ \\
\hline
\end{tabular}

b) Klinikai tünetekkel járó fertőzés esetén

\begin{tabular}{lcll}
\hline Indikációk & $\begin{array}{l}\mathrm{T}+/ \mathrm{I}+ \\
(\mathrm{N}=58)\end{array}$ & $\begin{array}{l}\mathrm{T}-/ \mathrm{I}+ \\
(\mathrm{N}=12)\end{array}$ & $\mathrm{p}$ \\
\hline HBV & $2(3,4 \%)$ & $1(8,3 \%)$ & $\mathrm{NS}$ \\
HCV & $22(37,9 \%)$ & $6(50 \%)$ & $\mathrm{NS}$ \\
PSC & $4(6,9 \%)$ & $2(16,7 \%)$ & $\mathrm{NS}$ \\
Egyéb & $30(51,7 \%)$ & $3(25 \%)$ & $\mathrm{NS}$ \\
\hline
\end{tabular}

2. táblázat $\mid$ Donor és recipiens demográfiai adatok Pozitív tenyésztés esetén

\begin{tabular}{lccc}
\hline & $\begin{array}{l}\mathrm{T}+/ \mathrm{I}+ \\
(\mathrm{N}=58)\end{array}$ & $\begin{array}{l}\mathrm{T}+/ \mathrm{I}- \\
\mathrm{N}=132)\end{array}$ & $\mathrm{p}$ \\
\hline Donor & & & \\
Életkor & $40,3 \pm 13,9$ & $39,5 \pm 14$ & $\mathrm{NS}$ \\
Nem (férfi) & $31(53,4 \%)$ & $70(53 \%)$ & $\mathrm{NS}$ \\
BMI-érték & $23 \pm 3,5$ & $23,6 \pm 3,4$ & $\mathrm{NS}$ \\
ITO (napok) & $3 \pm 2,8$ & $2,6 \pm 2,3$ & $\mathrm{NS}$ \\
Transzfúzió (E) & $0,69 \pm 2,2$ & $0,95 \pm 2,2$ & $\mathrm{NS}$ \\
EDC (0-6) & $1,57 \pm 1,2$ & $1,52 \pm 1$ & $\mathrm{NS}$ \\
Recipiens & & & $\mathrm{NS}$ \\
Életkor & $47,9 \pm 13,2$ & $45,3 \pm 13,8$ & $\mathrm{NS}$ \\
Nem (férfi) & $33(56,9 \%)$ & $81(61,4 \%)$ & $\mathrm{NS}$ \\
BMI & $25,6 \pm 4,5$ & $25,6 \pm 4,5$ & $\mathrm{NS}$ \\
Child-Pugh-score & $9 \pm 2$ & $8,4 \pm 1,7$ & $\mathrm{NS}$ \\
MELD-score & $18,8 \pm 10,5$ & $13,8 \pm 4,4$ & $\mathrm{NS}$ \\
Pre-OLT HRS & $17(29,3 \%)$ & $27(20,4 \%)$ & 0,01 \\
Pre-OLT DM & $8(13,8 \%)$ & $26(19,7 \%)$ & $\mathrm{NS}$ \\
Pre-OLT & $17(29,3 \%)$ & $27(20,4 \%)$ & \\
encephalopathia & & $36(27,3 \%)$ & \\
Pre-OLT & $15(25,9 \%)$ & $110(83,3 \%)$ & \\
varixvérzés & & & \\
OLT-Crossclamp & $45(77,6 \%)$ & \\
\hline & & & \\
\hline
\end{tabular}

$\mathrm{BMI})$, továbbá nem volt különbség a marginális donorok arányában sem. Mindezek alapján elmondható, hogy a preoperatív donortényezők tekintetében is homogén betegcsoportokat hasonlítottunk össze.
3. táblázat Donor és recipiens demográfiai adatok -

Klinikai tünetekkel járó posztoperatív fertózés esetén

\begin{tabular}{|c|c|c|c|}
\hline & $\begin{array}{l}\mathrm{T}+/ \mathrm{I}+ \\
(\mathrm{N}=58)\end{array}$ & $\begin{array}{l}\mathrm{T}-/ \mathrm{I}+ \\
(\mathrm{N}=12)\end{array}$ & $\mathrm{p}$ \\
\hline \multicolumn{4}{|l|}{ Donor } \\
\hline Életkor & $40,3 \pm 13,9$ & $35,6 \pm 15,6$ & NS \\
\hline Nem (férfi) & $31(53,4 \%)$ & $9(75 \%)$ & 0,57 \\
\hline BMI-érték & $23 \pm 3,5$ & $22,5 \pm 3,6$ & NS \\
\hline ITO (napok) & $3 \pm 2,8$ & $3 \pm 1,6$ & NS \\
\hline Transzfúzió (E) & $0,69 \pm 2,2$ & $0,67 \pm 2$ & NS \\
\hline $\operatorname{EDC}(0-6)$ & $1,57 \pm 1,2$ & $2,2 \pm 1,9$ & NS \\
\hline \multicolumn{4}{|l|}{ Recipiens } \\
\hline Életkor & $47,9 \pm 13,2$ & $45 \pm 17,4$ & NS \\
\hline Nem (férfi) & $33(56,9 \%)$ & $9(75 \%)$ & NS \\
\hline $\mathrm{BMI}$ & $25,6 \pm 4,5$ & $25,9 \pm 6,8$ & NS \\
\hline Child-Pugh-score & $9 \pm 2$ & $8,6 \pm 1,5$ & NS \\
\hline MELD-score & $18,8 \pm 10,5$ & $14,6 \pm 3,7$ & NS \\
\hline Pre-OLT HRS & $17(29,3 \%)$ & $1(8,3 \%)$ & NS \\
\hline Pre-OLT DM & $8(13,8 \%)$ & $1(8,3 \%)$ & NS \\
\hline $\begin{array}{l}\text { Pre-OLT } \\
\text { encephalopathia }\end{array}$ & $17(29,3 \%)$ & $2(16,7 \%)$ & NS \\
\hline $\begin{array}{l}\text { Pre-OLT } \\
\text { varixvérzés }\end{array}$ & $15(25,9 \%)$ & $1(8,3 \%)$ & NS \\
\hline OLT-Crossclamp & $45(77,6 \%)$ & $9(75 \%)$ & NS \\
\hline
\end{tabular}

A recipiensek májátültetés előtti állapotát összehasonlítottuk az egyes csoportokban. Azoknál a betegeknél, akik a $\mathrm{T}+\mathrm{I}+$ csoportba kerültek, magasabb átlagos MELD-pontszámot $(18,8 \pm 10,5$ vs. $13,8 \pm 4,4 ; \mathrm{p}=0,01)$ észleltünk, valamint azt, hogy gyakrabban volt észlelhető HRS. A perioperatív időszak alatt a mütéthez közvetlenül kapcsolódó időintervallumot értettük, beleértve az intenzív osztályon eltöltött időt is.

A perioperatív időszak adatait is összehasonlítottuk. A mütét során és után adott transzfúzió mennyisége szignifikáns különbséget mutatott a $\mathrm{T}+\mathrm{I}+$ és a $\mathrm{T}+\mathrm{I}-$ csoportban. A $\mathrm{T}+\mathrm{I}+$ csoportban levő betegek perioperatív folyadékpótlási igénye, elsősorban az intraoperatív vértranszfúziós igény nagyobb volt, a betegek hosszabb ideig szorultak ápolásra az intenzív osztályon, és ezen belül hosszabb ideig igényeltek gépi lélegeztetést. A T-I+ csoport szignifikánsan több thrombocytakészítményt kapott, szemben a $\mathrm{T}+\mathrm{I}+$ csoporttal. Az eredményeket a 4 . a) és 4. b) táblázat foglalja össze. Idetartozik a profilaktikusan adott antibiotikumok összehasonlítása. Ebben a tekintetben sem volt különbség. A hideg és meleg ischaemiás idő (CIT és WIT), valamint az intenzív terápiás kezelés és ezen belül a gépi lélegeztetés időtartamával kapcsolatos összehasonlító eredményeket az 5. táblázat mutatja be. A profilaktikus antibiotikumok és kezdeti calcineurininhibitorokkal kapcsolatos összehasonlítást a 6. táblázat mutatja. 
4. táblázat | Vérkészítmény- és folyadékpótlás a perioperatív időszakban

a) Pozitív tenyésztési leletek esetén fertőzés megléte és hiánya mellett

\begin{tabular}{llll}
\hline & $\begin{array}{l}\mathrm{T}+/ \mathrm{I}+ \\
(\mathrm{N}=58)\end{array}$ & $\begin{array}{l}\mathrm{T}+/ \mathrm{I}- \\
(\mathrm{N}=132)\end{array}$ & $\mathrm{p}$ \\
\hline $\begin{array}{l}\text { Intraoperatív } \\
\text { transzfúzió (E) }\end{array}$ & $7,8 \pm 5,5$ & $5,9 \pm 5,7$ & $\mathrm{NS}$ \\
$\begin{array}{l}\text { Intraoperatí } \\
\text { folyadék (ml) }\end{array}$ & $12381 \pm 6886$ & $9485 \pm 4643$ & 0,02 \\
$\begin{array}{l}\text { Öszes perioperatív } \\
\text { transzfúzió }(E)\end{array}$ & $20 \pm 23,6$ & $11,6 \pm 13,7$ & 0,02 \\
$\begin{array}{l}\text { FFP (ml) } \\
\text { Thrombocyta }(\mathrm{ml})\end{array}$ & $333,4 \pm 181,4$ & $312,3 \pm 193,4$ & $\mathrm{NS}$ \\
\hline
\end{tabular}

b) Posztoperatív fertőzés klinikai tünetei esetén, tenyésztési eredményektôl függően

\begin{tabular}{llll}
\hline & $\begin{array}{l}\mathrm{T}+/ \mathrm{I}+ \\
(\mathrm{N}=58)\end{array}$ & $\begin{array}{l}\mathrm{T}-/ \mathrm{I}+ \\
(\mathrm{N}=12)\end{array}$ & $\mathrm{p}$ \\
\hline $\begin{array}{l}\text { Intraoperatív } \\
\text { transzfúzió }(\mathrm{E})\end{array}$ & $7,8 \pm 5,5$ & $8,25 \pm 9,7$ & $\mathrm{NS}$ \\
$\begin{array}{l}\text { Intraoperatív } \\
\text { folyadék }(\mathrm{ml})\end{array}$ & $12381 \pm 6886$ & $13628 \pm 12963$ & $\mathrm{NS}$ \\
$\begin{array}{l}\text { Összes } \\
\text { perioperatív } \\
\text { transzfúzió }(\mathrm{E})\end{array}$ & $20 \pm 23,6$ & $18,6 \pm 21,5$ & $\mathrm{NS}$ \\
$\begin{array}{l}\text { FFP (ml) } \\
\text { Thrombocyta }(m l)\end{array}$ & $333,4 \pm 181,4$ & $549 \pm 320$ & \\
\hline
\end{tabular}

5. táblázat | Hideg és meleg ischaemiás idő, intenzív osztályon töltött idő

a) Pozitív tenyésztési lelet esetén

\begin{tabular}{llll}
\hline & $\begin{array}{l}\mathrm{T}+/ \mathrm{I}+ \\
(\mathrm{N}=58)\end{array}$ & $\begin{array}{l}\mathrm{T}+/ \mathrm{I}- \\
(\mathrm{N}=132)\end{array}$ & $\mathrm{p}$ \\
\hline $\begin{array}{l}\text { Mútét idótartama } \\
\text { (perc) }\end{array}$ & $445 \pm 82,7$ & $436 \pm 91,8$ & $\mathrm{NS}$ \\
WIT (perc) & $57,4 \pm 15,6$ & $54,4 \pm 14,8$ & $\mathrm{NS}$ \\
CIT (perc) & $474 \pm 128,7$ & $446 \pm 141$ & $\mathrm{NS}$ \\
$\begin{array}{l}\text { Gépi lélegeztetés } \\
\text { (nap) }\end{array}$ & $8,25 \pm 15,3$ & $0,98 \pm 1,4$ & $<0,01$ \\
ITO (nap) & $21,8 \pm 30,4$ & $7,6 \pm 6,4$ & $<0,01$ \\
\hline
\end{tabular}

b) Klinikai tünetekkel járó posztoperatív fertőzés esetén

\begin{tabular}{|c|c|c|c|}
\hline & $\begin{array}{l}\mathrm{T}+/ \mathrm{I}+ \\
(\mathrm{N}=58)\end{array}$ & $\begin{array}{l}\mathrm{T}-/ \mathrm{I}+ \\
(\mathrm{N}=12)\end{array}$ & $\mathrm{p}$ \\
\hline $\begin{array}{l}\text { Mütét időtartama } \\
\text { (perc) }\end{array}$ & $445 \pm 82,7$ & $421,5 \pm 140,3$ & NS \\
\hline$W I T($ perc $)$ & $57,4 \pm 15,6$ & $73 \pm 23,2$ & 0,02 \\
\hline CIT (perc) & $474 \pm 128,7$ & $520 \pm 140,5$ & NS \\
\hline $\begin{array}{l}\text { Intubációs idő } \\
\text { (nap) }\end{array}$ & $8,25 \pm 15,3$ & $7 \pm 8,9$ & NS \\
\hline ITO (nap) & $21,8 \pm 30,4$ & $22,2 \pm 21,7$ & NS \\
\hline
\end{tabular}

\begin{tabular}{l|l} 
6. táblázat & $\begin{array}{l}\text { Alkalmazott antibiotikus profilaxis, calcineurininhibitor, és en- } \\
\text { nek szérumszintje }\end{array}$
\end{tabular}

a) Pozitív tenyésztési leletek esetén

\begin{tabular}{lccc}
\hline & $\begin{array}{l}\mathrm{T}+/ \mathrm{I}+ \\
\mathrm{N}=58)\end{array}$ & $\begin{array}{l}\mathrm{T}+/ \mathrm{I}- \\
(\mathrm{N}=132)\end{array}$ & $\mathrm{p}$ \\
\hline $\begin{array}{l}\text { Amoxycillin/ } \\
\text { Ciprofloxacin }\end{array}$ & $45(77,6 \%)$ & $112(84,8 \%)$ & $\mathrm{NS}$ \\
$\begin{array}{l}\text { Rocephin } \\
\text { Tazobactam }\end{array}$ & $11(19 \%)$ & $18(13,6 \%)$ & $\mathrm{NS}$ \\
$\begin{array}{l}\text { Tacrolimus (TAC) } \\
\text { alkalmazása }\end{array}$ & $54(93,1 \%)$ & $125(94,7 \%)$ & $\mathrm{NS}$ \\
$\begin{array}{l}\text { CyA-szérumszint } \\
(1-4 \text { nap) }\end{array}$ & $412 \pm 206$ & $454,3 \pm 222$ & $\mathrm{NS}$ \\
$\begin{array}{l}\text { TAC-szérumszint } \\
(1-4 \text { nap) }\end{array}$ & $20 \pm 8,3$ & $20,8 \pm 8,2$ & $\mathrm{NS}$ \\
$\begin{array}{l}\text { MMF alkalmazása } \\
\text { MM }\end{array}$ & $55(94,8 \%)$ & $122(92,4 \%)$ & $\mathrm{NS}$ \\
\hline
\end{tabular}

b) Klinikai tünetekkel járó fertőzés esetén

\begin{tabular}{lccc}
\hline & $\begin{array}{l}\mathrm{T}+/ \mathrm{I}+ \\
\mathrm{N}=58)\end{array}$ & $\begin{array}{l}\mathrm{T}-/ \mathrm{I}+ \\
(\mathrm{N}=12)\end{array}$ & $\mathrm{p}$ \\
\hline $\begin{array}{l}\text { Amoxycillin/ } \\
\text { Ciprofloxacin }\end{array}$ & $45(77,6 \%)$ & $6(50 \%)$ & $\mathrm{NS}$ \\
$\begin{array}{l}\text { Rocephin } \\
\text { Tazobactam }\end{array}$ & $11(1,7 \%)$ & 0 & $\mathrm{NS}$ \\
TAC alkalmazása & $54(93,1 \%)$ & $5(41,7 \%)$ & $\mathrm{NS}$ \\
$\begin{array}{l}\text { CyA-szérumszint } \\
\text { (1-4 nap) }\end{array}$ & $412 \pm 206$ & $178 \pm 16,2$ & $\mathrm{NS}$ \\
$\begin{array}{l}\text { TAC-szérum } \\
\text { (1-4nap) }\end{array}$ & $20 \pm 8,3$ & $17,3 \pm 6$ & $\mathrm{NS}$ \\
MMF alkalmazása & $55(94,8 \%)$ & $12(100 \%)$ & $\mathrm{NS}$ \\
\hline
\end{tabular}

A mütét utáni szövődmények előfordulási gyakoriságát is összehasonlítottuk. Ezt a 7. táblázat mutatja be. A $\mathrm{T}+\mathrm{I}+$ csoportban $7(12,3 \%)$ esetben alakult ki cholangitis, 17 esetben $(29,8 \%)$ fordult elő hasúri és 28 esetben $(49,1 \%)$ pulmonalis eredetű fertőzés. Posztoperatív fertőzés gyakrabban lépett fel kezdeti csökkent graftmúködési zavar (IPF), akut veseelégtelenség, epeúti szövődmény és hasứri vérzés után. Ezek között a betegek között, értelemszerúen, nagyobb arányban került sor sebészi vagy radiológiai reintervencióra is. Az epeúti szövődményeket a továbbiakban részletesen is vizsgáltuk (8. táblázat). A posztoperatív fertőzések kialakulása öszszefüggött mind a korai epeúti szövődményekkel, mind a különböző súlyosságú cholangitis kialakulásával. Az epeúti csorgás, stenosis és az epeúti nekrózis aránya nem volt magasabb fertőzés mellett $(\mathrm{T}+\mathrm{I}+$ csoport), azonban ebben a csoportban gyakrabban végeztek epeúti reintervenciót. Ebben az okozat összefüggésben egyértelmú, hogy az epeúti stenosis (pangás), szivárgás talaján már egyébként is magasabb kockázatú fertózés az ismételt beavatkozások során - és részben hatására - aktiválódhatott, manifeszt cholangitis formájában. 
7. táblázat | Posztoperatív szövődmények

a) Pozitív tenyésztési lelet esetén

\begin{tabular}{lccc}
\hline & $\begin{array}{l}\mathrm{T}+/ \mathrm{I}+ \\
\mathrm{N}=58)\end{array}$ & $\begin{array}{l}\mathrm{T}+/ \mathrm{I}- \\
(\mathrm{N}=132)\end{array}$ & $\mathrm{p}$ \\
\hline PNF (\%) & $2(3,4 \%)$ & $1(0,8 \%)$ & $\mathrm{NS}$ \\
IPF (\%) & $17(29,3 \%)$ & $9(6,8 \%)$ & $<0,01$ \\
Hasüri vérzés & $22(38 \%)$ & $34(25,8 \%)$ & 0,06 \\
Vascularis & $7(12,1 \%)$ & $27(20,4 \%)$ & $\mathrm{NS}$ \\
szövődmény & & & \\
$\begin{array}{l}\text { Reintervenció } \\
\text { sebészi, radiológiai) }\end{array}$ & $40(69 \%)$ & $70(53 \%)$ & 0,04 \\
$\begin{array}{l}\text { Epeúti reintervenció } \\
\text { Veseelégtelenség }\end{array}$ & $21(36,2 \%)$ & $27(20,4 \%)$ & 0,01 \\
Akut rejekció & $30(51,7 \%)$ & $18(13,6 \%)$ & $<0,001$ \\
Szteroidbólus & $14(24,1 \%)$ & $32(24,2 \%)$ & $\mathrm{NS}$ \\
$\begin{array}{l}\text { De novo diabetes } \\
\text { mellitus (NODAT; \%) }\end{array}$ & $8(13,8 \%)$ & $21(16 \%)$ & $\mathrm{NS}$ \\
\hline
\end{tabular}

b) Klinikai tünetekkel járó posztoperatív fertőzés esetén

\begin{tabular}{lcll}
\hline & $\begin{array}{l}\mathrm{T}+/ \mathrm{I}+ \\
(\mathrm{N}=58)\end{array}$ & $\begin{array}{l}\mathrm{T}-/ \mathrm{I}+ \\
(\mathrm{N}=12)\end{array}$ & $\mathrm{p}$ \\
\hline PNF & $2(3,4 \%)$ & 0 & $\mathrm{NS}$ \\
IPF & $17(29,3 \%)$ & $2(16,7 \%)$ & $\mathrm{NS}$ \\
Hasüri vérzés & $22(38 \%)$ & $1(8,3 \%)$ & 0,04 \\
Vascularis & $7(12,1 \%)$ & $1(8,3 \%)$ & $\mathrm{NS}$ \\
szövődmény & & & \\
$\begin{array}{l}\text { Reintervenció } \\
\text { (sebészi, radiológiai })\end{array}$ & $40(69 \%)$ & $7(58,3 \%)$ & $\mathrm{NS}$ \\
$\begin{array}{l}\text { Epeúti reintervenció } \\
\text { Veseelégtelenség }\end{array}$ & $21(36,2 \%)$ & $3(25 \%)$ & $\mathrm{NS}$ \\
$\begin{array}{l}\text { Akut rejekció } \\
\text { Szteroidbólus }\end{array}$ & $9(51,7 \%)$ & $5(41,7 \%)$ & $\mathrm{NS}$ \\
$\begin{array}{l}\text { De novo diabetes } \\
\text { mellitus (NODAT; \%) }\end{array}$ & $8(13,8 \%)$ & $2(16,7 \%)$ & $\mathrm{NS}$ \\
\hline
\end{tabular}

Akiknél mikrobás fertőzés alakult ki a mưtétet követő időszakban $(\mathrm{T}+\mathrm{I}+)$, a posztoperatív (negyedik hónapnál korábban észlelt) hepatitis C-vírus-rekurrencia gyakorisága is magasabb volt azokhoz képest, akiknél nem találtunk fertőzést $(\mathrm{T}+\mathrm{I}-)$. A különbség szignifikáns ( $\mathrm{p}=$ 0,045). Ennek magyarázata nem egyértelmú, és lehet statisztikai egybeesés, illetve párhuzamosság is. A HCVrekurrenciára hajlamosító tényezők ugyanis hasonlóak a posztoperatív bakteriális fertőzés kockázati faktoraihoz.

Összehasonlítottuk a kumulatív beteg- és grafttúlélést is (1. és 2. ábra). Azoknál a betegeknél, akiknél kialakult a posztoperatív időszakban infekció, a kumulatív betegtúlélés szignifikánsan rosszabb volt azokhoz képest, akiknél nem volt fertőzés. Az 1. ábrán látható, hogy mindkét csoportban, a pozitív tenyésztési leletek mellett, infekció kialakulása esetén az 1, 3, 5 és 10 éves betegtúlélés 70\%, $56 \%, 56 \%$ és 46\%, míg posztoperatív infekció nélkül ez
8. táblázat | Epeúti szövődmények a vizsgált csoportokban

a) Pozitív tenyésztés esetén

\begin{tabular}{llll}
\hline & $\begin{array}{l}\mathrm{T}+/ \mathrm{I}+ \\
\mathrm{N}=58)\end{array}$ & $\begin{array}{l}\mathrm{T}+/ \mathrm{I}- \\
(\mathrm{N}=132)\end{array}$ & $\mathrm{p}$ \\
\hline $\begin{array}{l}\text { Összes epeúti } \\
\text { szövödmény }\end{array}$ & $23(39,6 \%)$ & $29(22 \%)$ & $<0,01$ \\
$\begin{array}{l}\text { Korai epeúti } \\
\text { szövődmény (<3 hó) }\end{array}$ & $13(22,4 \%)$ & $17(12,9 \%)$ & 0,08 \\
$\begin{array}{l}\text { Késői epeúti } \\
\text { szövő́dmény (>3 hó) }\end{array}$ & $10(17,2 \%)$ & $12(9 \%)$ & $\mathrm{NS}$ \\
$\begin{array}{l}\text { Cholangitis } \\
\text { Epecsorgás }\end{array}$ & $10(17,2 \%)$ & $14(10,6 \%)$ & $\mathrm{NS}$ \\
$\begin{array}{l}\text { Stenosis } \\
\text { Korai stenosis }\end{array}$ & $5(2(20,7 \%)$ & $17(12,9 \%)$ & $\mathrm{NS}$ \\
Késői stenosis & $7(12 \%)$ & $5(3,8 \%)$ & $\mathrm{NS}$ \\
Nekrózis & $5(8,6 \%)$ & $5(3,8 \%)$ & $\mathrm{NS}$ \\
\hline
\end{tabular}

b) Klinikai tünetekkel járó posztoperatív fertőzés esetén

\begin{tabular}{lcll}
\hline & $\begin{array}{c}\mathrm{T}+/ \mathrm{I}+ \\
(\mathrm{N}=58)\end{array}$ & $\begin{array}{l}\mathrm{T}-/ \mathrm{I}+ \\
(\mathrm{N}=12)\end{array}$ & $\mathrm{p}$ \\
\hline $\begin{array}{l}\text { Összes epeúti } \\
\text { szövődmény }\end{array}$ & $23(39,6 \%)$ & $3(25 \%)$ & $\mathrm{NS}$ \\
$\begin{array}{l}\text { Korai epeúti } \\
\text { szövődmény (<3 hó) }\end{array}$ & $13(22,4 \%)$ & $1(8,3 \%)$ & $\mathrm{NS}$ \\
$\begin{array}{l}\text { Késői epeúti } \\
\text { szövődmény (>3 hó) }\end{array}$ & $10(17,2 \%)$ & $2(16,6 \%)$ & $\mathrm{NS}$ \\
$\begin{array}{l}\text { Cholangitis } \\
\text { Epecsorgás }\end{array}$ & $10(17,2 \%)$ & 0 & \\
Stenosis & $12(20,7 \%)$ & $3(25 \%)$ & 0,07 \\
Korai stenosis & $5(8,6 \%)$ & $1(8,3 \%)$ & $\mathrm{NS}$ \\
Késói stenosis & $7(12 \%)$ & $2(16,6 \%)$ & $\mathrm{NS}$ \\
Nekrózis & $5(8,6 \%)$ & 0 & $\mathrm{NS}$ \\
\hline
\end{tabular}

$94 \%, 87 \%, 85 \%$ és $76 \%$ ( $\mathrm{p}<0,001)$. Hasonlóan, az 1, 3, 5 és 10 éves grafttúlélés is jelentősen rosszabb volt a T+Icsoportban: $92,2 \%, 85,4 \%, 81,1 \%, 68,7 \%$, mint a $\mathrm{T}+\mathrm{I}+$ csoportban: $70,4 \%, 56 \%, 56 \%, 45,8 \%(\mathrm{p}<0,001)$. Ez érthetö, hiszen a $\mathrm{T}+\mathrm{I}+$ csoportban szignifikánsan magasabb arányban fordult elő a posztoperatív veseelégtelenség ( $54 \%$ vs. $14 \%)$ és szepszis $(35,1 \%$ vs. $25 \%)$, mint az I-T+ csoportban.

Ha a posztoperatív időszakban fertőzést elszenvedő csoportot tovább bontjuk abból a szempontból, hogy ehhez társult-e pozitív tenyésztési lelet (I+ mellett T+ vagy $\mathrm{T}-$ ), akkor a 2. ábrán látható, hogy - meglepően a negatív tenyésztési lelet mellett rosszabb az első éves túlélés, viszont a 3, 5 és 10 éves adatokban nincs különbség. A korai betegvesztésre magyarázatul szolgálhat, hogy ebben a csoportban fó halálokként egyáltalán nem szerepelt MOF/szepszis, hanem kardiális dekompenzáció, vírusrekurrencia, cardiovascularis szövődmény, egyegy esetben tumorrekurrencia, illetve pulmonalis embo- 


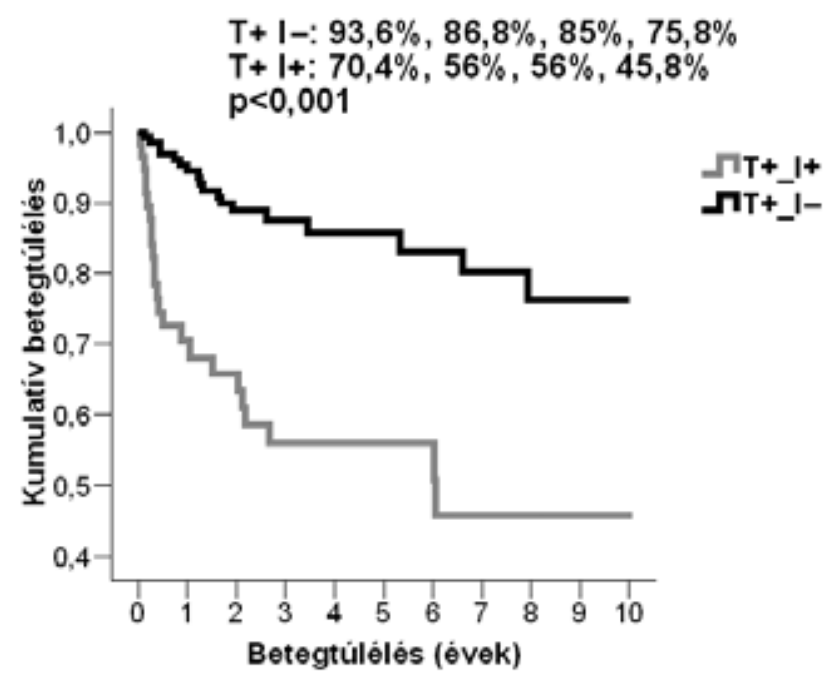

1. ábra $\quad$ Kumulatív betegtúlélés posztoperatív fertőzés kialakulása esetén, összehasonlítva eseménytelen posztoperatív időszak mellett

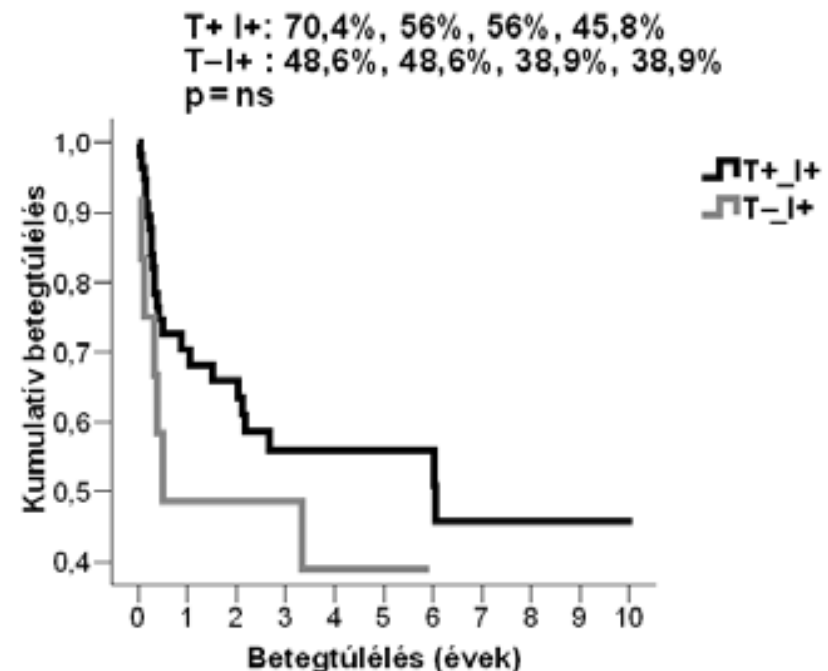

2. ábra

Kumulatív betegtúlélés posztoperatív fertőzés esetén, attól függően, hogy a fertőzés mellett pozitív tenyésztési leletet igazoltunk-e vagy sem

lia szerepelt. Ezzel szemben pozitív tenyésztési leletek mellett 11 betegnél MOF, 5 betegnél graftelégtelenség, kettőnél tumorrekurrencia és öt betegnél ismeretlen okból történt halálozás.

\section{A tenyésztési minták forrása és az eredmények spektruma}

A 2003 és 2013 közötti időszakot tekintve a májátültetett betegek tenyésztés céljából vett mintáit vizsgáltuk. Ez 281 mintát jelentett. 188 betegnél $(66,9 \%)$ igazolódott bakteriális és mindössze két esetben (1\%) fordult elő önmagában fungális eredet. A 190 beteg közül, akiknél a tenyésztés pozitív eredményt adott, 132 esetben nem volt fertőzés. Ők kerültek a T+I- csoportba $(69,5 \%)$.
A $\mathrm{T}+\mathrm{I}+$ csoportba 58 beteg tartozott, ez a 190 beteg 30,5\%-a. A T+I+ csoport 58 betege közül 34-nél alakult ki bakteriális $(58,6 \%)$ és 21 betegnél kevert (bakteriális+gomba) fertőzés $(41,3 \%)$ (3. táblázat).

A továbbiakban a $\mathrm{T}+\mathrm{I}+$ csoport betegeinél vizsgáltuk a baktériumok spektrumát, mivel ez a csoport jelentette a korábbi eredmények alapján és a gyakorlati klinikai szempont szerint is (pozitív tenyésztés klinikai tünetek mellett) a valódi vizsgálati célcsoportot. Gram-pozitív baktériumok a tenyésztések 28,6\%-ában ( $\mathrm{N}=16)$ mutathatóak ki. Emellett a Gram-negatív baktériumok 9\%-ban $(\mathrm{N}=5)$, illetve a Gram-pozitív és -negatív kórokozó együttesen $60,7 \%$-ban $(\mathrm{N}=34)$ fordultak elő. Érdekességképpen elvégeztük a spektrum vizsgálatát azoknál is, akik pozitív tenyésztési lelet mellett nem mutattak klinikai tüneteket (kontamináció, kolonizáció), azaz a T+Icsoportnál. Az eredmények a következők: a tenyészetek $73 \%$-ban $(\mathrm{N}=97)$ bakteriális eredetüek, azonban $26,3 \%$ ban $(\mathrm{N}=35)$ kevert fertőzést találtunk. A bakteriális tenyészetek 37\%-a ( $\mathrm{N}=49)$ Gram-pozitív, 7,5\%-a ( $\mathrm{N}=$ 10) Gram-negatív baktérium. Gram-pozitív és -negatív kórokozó együttesen a tenyészetek $54,9 \%$-ában $(\mathrm{N}=73)$ jelenik meg. A multidrug-rezisztencia kialakulása a $\mathrm{T}+\mathrm{I}+$ csoportban $63,2 \%$, a T+I- csoportban $53 \%$ volt. A különbség szignifikáns, $\mathrm{p}=0,034$. A fentieket a 3 ábra mutatja be.

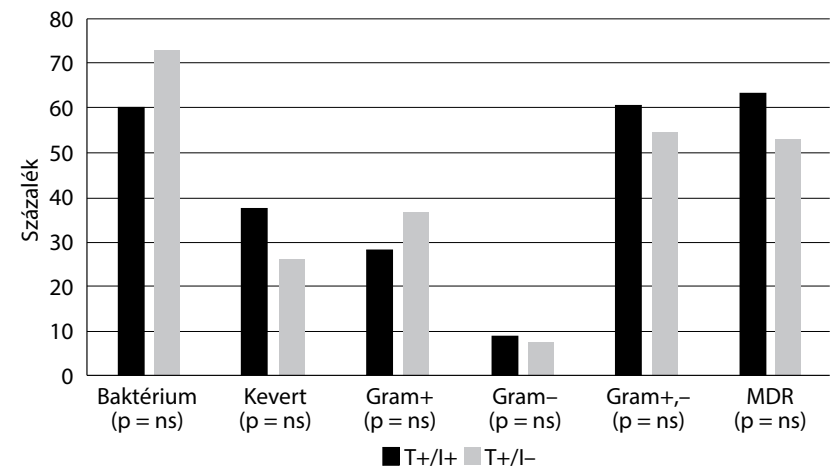

3. ábra

A tenyésztések eredményei - I. Az első két oszloppár a bakteriális, illetve kevert (gomba+bakteriális) fertőzések arányát mutatja. A harmadik, negyedik és ötödik oszloppár a Gram pozitív/ negatív, illetve vegyes kultúrákat, és az utolsó oszloppár az MDR arányát. Az egyes oszloppárokon belül a sötétebb oszlop azokat a betegek jelöli, akiknél a pozitív tenyésztési eredmény mellett infekció is zajlott, a világosabb oszlop azt, ahol nem. MDR = multidrug-rezisztens kórokozók

\section{A részletesebb bakteriális spektrumvizsgálat eredménye (4. és 5. ábra)}

A leggyakrabban azonosított kórokozó a koaguláznegativ Staphylococcus volt $(\mathrm{N}=92)$. Staphylococcus aureus 86 esetben, Enterococcus faecalis pedig 70 esetben tenyészett ki. Számos mintában fordult elö Candida albicans $(\mathrm{N}=57)$, Pseudomonas aeruginosa $(\mathrm{N}=29)$ és Klebsiella pneumoniae $(\mathrm{N}=24)$. . aeruginosa esetén a két csoport 


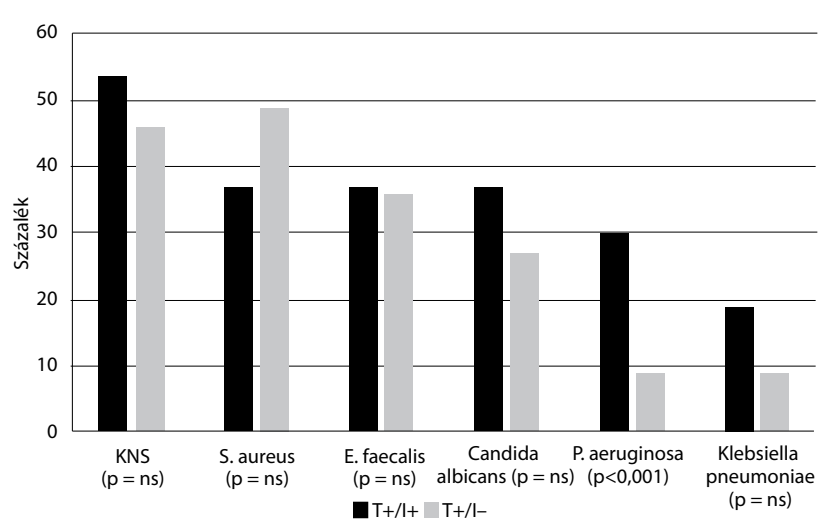

4. ábra

A tenyésztések eredményei - II. Az egyes oszloppárokon belül a sötétebb oszlop azokat a betegeket jelöli, akiknél a pozitív tenyésztési eredmény mellett infekció is zajlott, a világosabb oszlop azt, ahol nem. A Pseudomonas fertőzés kiemelkedően magas arányban fordult elő
K. pneumoniae+Str. alfa haemol.

E. faecalis+Str. alfa haemol.

K. pneumoniae+C. albicans

Acinetobacter sp. + E. faecalis + C. albicans

S. aureus+Str. alfa haem.

Acinetobacter spp.+E. coli+C. albicans

E. coli+K. oxocyta+Pseudomonas...

C. albicans $+E$. faecalis $+K$. pneumoniae

S. aureus+E. faecalis+St. coag. neg.

St. coag. neg. + E. coli

Acinetobacter spp.

Pseudomonas aeruginosa+Proteus sp.

C. albicans $+E$. coli $+E$. faecalis

E. coli+Pseudomonas aeruginosa

S. aureus+Pseudomonas aeruginosa...+

E. coli+K. pneumoniae

E. colits. aureus

S. aureus+Str. pneumoniae

St. coag. neg.+Str. alfa haem.

E. faecalis+St. coag. neg.

Streptococcus pneumoniae

Pseudomonas aeruginosa

Escherichia coli

Enterococcus faecalis

Staphylococcus coag. neg.

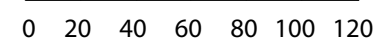

között szignifikáns különbséget tapasztaltunk ( $\mathrm{p}<0,001)$, azaz $P$. aeruginosa gyakrabban okozott klinikai tünetekkel járó fertőzést, de hasonló - bár statisztikailag nem szignifikáns - eltérést mutatott a Klebsiella és Candida is. A kórokozók többsége különböző kombinációkban fordul elő, ennek részleteit az 5. ábra szemlélteti. Jól látható, hogy a Klebsiella, Pseudomonas törzsek és a Candida elsősorban valódi klinikai fertőzés részeként fordultak elő.

\section{A posztoperativ, klinikai tünetekkel járó fertózések gyakoriságának trendje a magyar májátültetési programban}

A hazai májátültetési programban 2003-tól vizsgáltuk az eredményeket. A májtranszplantált betegek kevesebb mint 40\%-ánál alakult ki valamilyen mikrobás fertőzés, csökkenő vagy növekvő trend nem volt kimutatható.

Fertőzés kialakulása esetén vizsgáltuk a szepszis előfordulási gyakoriságát. A pozitív tenyésztési lelettel rendelkezők $(\mathrm{T}+\mathrm{I}+)$ esetén 35,1\%-ban $(\mathrm{N}=20)$ alakult ki szepszis szövődményként, ez a negatív tenyésztési csoportban $(\mathrm{T}-\mathrm{I}+) 25 \%(\mathrm{~N}=3)$ volt. A különbség nem szignifikáns különbség, és alátámasztja azt a nézetünket, hogy pozitív tenyésztési lelet nélkül is kialakulhat akár szeptikus állapotig fajuló infekció az immunszupprimált betegekben.

Az eredményeket összehasonlítva korábbi összefoglaló közléseinkkel (35) megállapítható, hogy 1995-2004 között a szepszis gyakorisága a teljes, akkor vizsgált beteganyag esetén, azaz 190 beteg közül 45 esetben alakult ki $(22,6 \%)$, míg a jelen vizsgálat eredményei alapján ez 408 beteg esetén csak 23 beteget érintett, ez 5,6\%.

Az előzőekben már részletezettek szerint a szepszisre visszavezethető halálozás a $\mathrm{T}+\mathrm{I}+$ csoportban volt jellemző, míg a T-I+ csoportban inkább cardiovascularis okok szerepeltek. Mindkét csoportban voltak szeptikus betegek, de a $\mathrm{T}+\mathrm{I}+$ csoportban a betegek $33,3 \%$-át $(\mathrm{N}=10)$ vesztettük el szepszis/MOF következményeként, ezzel szemben a T-I+ csoportban nem történt szeptikus okra visszavezethető halálozás. A posztoperatív fertőzések forrását a 6 . ábra mutatja.

\section{Megbeszélés}

A májtranszplantáció mortalitását és morbiditását jelentősen befolyásolják a bakteriális infekciók. A diagnózis felállítása nehéz feladat, mivel sok esetben a klinikai tünetek hiányoznak vagy szegényesek [14]. A pozitív tenyésztés önmagában nem jelent fertőzést, azaz lehet kolonizáció is. Vizsgálatunkban ennek kizárását reprezentálta a T+I- csoport. Másrészt a kialakuló infekció ugyan az esetek túlnyomó többségében $(\mathrm{N}=58)$ pozitív tenyésztési lelettel jár együtt, de nem mindig $(\mathrm{N}=12)$. A fertőzés mellett észlelt pozitív és negatív tenyésztési csoportokban a szövődmények aránya és a kimenetel 


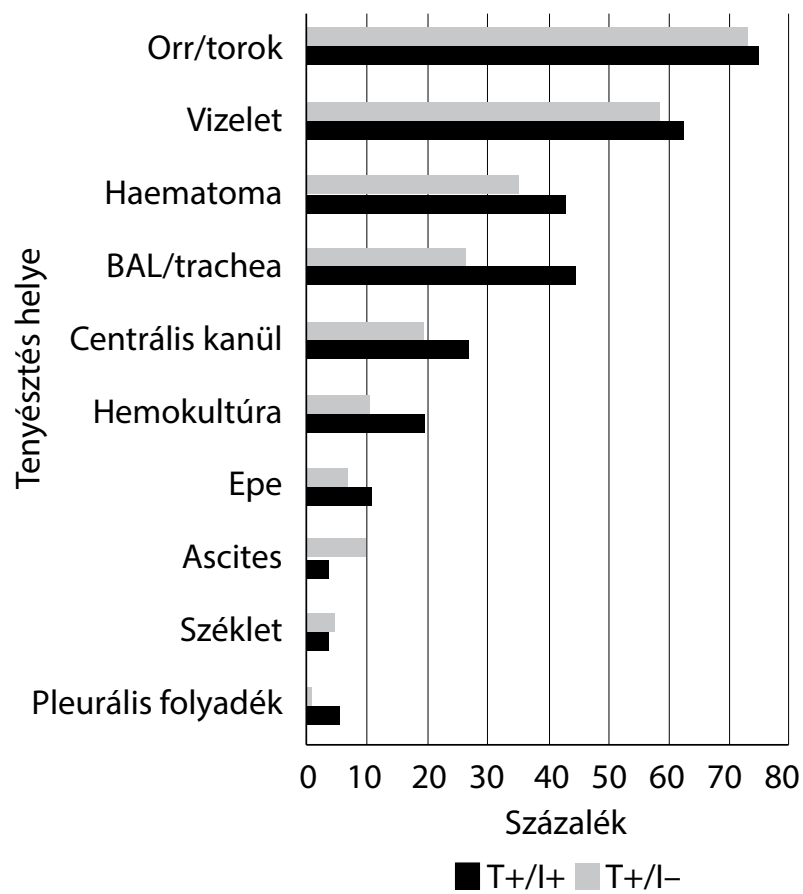

6. ábra A tenyésztések forrásai. Az egyes oszloppárokon belül a söté-
tebb oszlop azokat a betegeket jelöli, akiknél a pozitív tenyész-
tési eredmény mellett infekció is zajlott, a világosabb oszlop azt,
ahol nem. Látható, hogy az alsó légúti- és véráramfertőzések
kiemelkedő arányban fordultak elő

azonos volt. Tehát a negatív tenyésztési lelet nem zárja ki a fertőzéses szövődmények meglétét (a pozitív tenyésztés pedig nem jelent önmagában infekciót). A tenyésztés egyik előnye, hogy időben eszközt ad a kezelőorvos kezébe. Ismétlése nem felesleges akkor sem, ha egyszer negatív volt. A hazai eredmények azt mutatják, hogy a májátültetési program kezdetétől 2003-ig kialakult, majd csökkenő tendenciát mutató posztoperatív fertőzési arány megegyezik az UNOS által közölt adatokkal, miszerint a betegek körülbelül 50\%-ánál alakul ki fertőzés a májtranszplantációt követő első évben [15].

\section{Preoperatín jellemzôk és a fertözés}

A hazai adatok feldolgozása során azt tapasztaltuk, hogy eleve előrehaladottabb, súlyosabb májbetegségben szenvedtek azok a betegek, akiknél a posztoperatív időszakban bakteriális fertőzés alakult ki. Ehhez hasonló eredményekről számoltak be Karapanagiotou és mtsai, miszerint szignifikánsan magasabb a MELD értéke későbbi posztoperatív fertőzés esetén [14]. A fertőzés kialakulását a már jelen lévő társbetegségek is elősegíthetik, mint például a hepatopulmonalis szindróma (HPS) vagy a hepatorenalis szindróma (HRS). A cirrhoticus máj fokozottan fogékony a fertőzésekkel szemben. A máj által termelt komplementek csökkent szintézise kedvezőtlenül hat a Kupffer-sejt-funkcióra, megváltoztatja a neutrophil kemotaxist és a gyulladásos citokinek múkö- dését [16]. Ez csökkent baktericid funkciót eredményez. Az immunszuppresszív szerek alkalmazása, a széles spektrumú antibiotikumok használata, az elhúzódó mútéti idő, a sebészi technika komplexivitása és az invazív diagnosztikus eljárások a kritikus állapotban lévő betegek esetén az infekcióval szembeni fogékonyságot növelik. A politranszfúziós igény alapján lehet következtetni a beültetés nehézségeire, ebben az esetben hosszú a mútéti idő is, illetve rossz a preoperatív állapot [17]. Goldaracena és mtsai hasonló eredményekról számoltak be: abban a betegcsoportban, ahol posztoperatív bakteriális infekció alakult ki, a betegek $27 \%$-a kapott perioperatíve transzfúziót, ahol nem volt fertőzés, ott ez az arány csak 10\%-volt. A kutatócsoport hangsúlyozza, hogy a transzfúzió adása nagymértékben befolyásolja az intenzív osztályos kezelés, illetve a teljes kórházi kezelés időtartamát [18]. Avkan-Oguz és mtsai az intraoperatív időszakban a 6 egységnél (E) nagyobb mértékű transzfúziós igényt, illetve a 12 egységnél nagyobb mértékú FFP-igényt találták rizikófaktornak az infekció kialakulásának szempontjából [19]. Giunta és mtsai egyik 2013-as publikációjukban összefüggést találtak a mikrobiológiai lelet és a lélegeztetés időtartama között. Azoknál a betegeknél, akiknél nem alakult ki fertőzés, szignifikánsan rövidebb ideig tartott a gépi lélegeztetés, illetve az antimikrobiális kezelés. Ebben a csoportban a túlélési görbe is kedvezőbb volt [20]. Karapanagiotou és mtsai is hasonló eredményekről számolnak be [14]. A hat napnál hoszszabb intenzív osztályos kezelés a betegek számára rizikótényezőt jelent a bakteriális fertőzésekkel szemben [19]. Az endotrachealis tubus elhúzódó használata kedvez a Gram-negatív infekciók kialakulásának [17].

A szelektív béltraktus-dekontamináció az 1990-es évek elején általánosan elterjedt kezelési módszer volt. A májtranszplantált betegeknél a gyomor-bél traktus baktériumflórája - többségben Gram-negatív kórokozók - fontos forrása a bakteriális fertőzéseknek, különösen a mútétet követő első hónapban: ez az elmélet volt az alapja az SDD lehetséges preventív szerepének [21]. A várt pozitív hatások ellenére a legtöbb tanulmány nem tudta egyértelműen igazolni az SDD kedvező hatását a betegtúlélésre vonatkozóan. Az azonban ismert, hogy az esetek döntő többségében a gastrointestinalis rendszer bakteriális és fungális kolonizációja előzi meg a fertőzést. 1988-ban Wiesner és mtsai az SDD-t profilaktikus stratégiának tartották. A fertőzések incidenciája a transzplantációt követően markáns csökkenést mutatott (RRR relative risk reduction - 50\%) [22]. Az SDD antibiotikum-összetétele centrumonként más és más, és az alkalmazás időtartama sem egységes. Az SDD nagy hatékonyságot mutatott a kolonizációk csökkenésében is [11]. Felmerül a kérdés, vajon az SDD növeli-e az antimikrobiális rezisztenciát? Leone és mtsai növekvő MRSEesetszámot mutattak ki az SDD-vel kezelt betegek körében [23]. A multiplex komorbiditási tényezók folytán nincs egyértelmű válasz, mivel maga a sebészeti beavatkozás, az elhúzódó kórházi tartózkodás önmagukban is 
nagy kockázatot jelentenek a szerzett bakteriális és fungális rezisztencia kialakulására. A probiotikumok preventikus alkalmazása ígéretesnek bizonyult egyes szerzők szerint [13]. Mindazonáltal a csökkenő Gram-negatív eredetû fertőzésekkel szemben a Gram-pozitívak száma emelkedett SDD használatakor [11, 13], ráadásul a rezisztencia növekvő tendenciát mutatott [21]. A légzőrendszeri infekciók csökkenését több szerző összefüggésbe hozza a profilaktikus antibiotikumok alkalmazásával, mint az SDD, illetve a selective oropharyngeal decontamination (SOD) [24]. Az SDD megelőzi a Gram-negatív baktériumok, a $S$. aureus és élesztőgombák másodlagos kolonizációját, nem felszívódó antimikrobiális szerek használatával, az oropharynxban és a gastrointestinalis traktusban. A közlés szerint a SOD az SDD alternatívájaként jelent meg, a gépi lélegeztetéssel szerzett pneumonia prevenciójaként. Az SDD-ben részesült betegeknél a szerzett Enterobacteriaceae bacteraemia alacsonyabb incidenciája volt megfigyelhető az intenzív osztályokon, mint azoknál a betegeknél, akik SOD-ban részesültek. Összehasonlítva az SDD, illetve SOD-ban részesült betegeket a hagyományosan kezelt páciensekkel, a szerző szerint az előbbi csoportban jelentősen csökkent a $S$. aureus, P. aeruginosa és Enterobacteriaceae okozta bacteriaemia [25]. Az SDD-t a hazai gyakorlatban az 1995-1999 közötti időszakban alkalmazták, amelyre vizsgálatunk nem terjedt ki.

A májátültetés előtti intravénás antimikrobás profilaxis tekintetében is megoszlanak a vélemények. V. G. Agopian és mtsai intravénás ampicillin- és sulbactam- vagy piperacillin- és tazobactamprofilaxis alkalmazását javasolják a korai posztranszplantációs időszakban [26]. Nasia Safdar és mtsai harmadik generációs cephalosporin és aminoglikozid kombinációban való parenteralis adását, illetve per os polymyxin, gentamycin vagy fluorokinolok szedését ajánlják [11]. A hazai gyakorlatban a harmadik generációs cephalosporinokat és az igen széles hatásspektrumú imipenem, meropenem adását jelenleg nem alkalmazzák profilaxisként. A 2003 előtti gyakorlat ettől eltért $[4,5,27]$. Saját anyagunk vizsgálata is megerősíti, hogy kialakult fertőzés esetén magas a szepszis aránya, azaz szúk az a terápiás időintervallum, ahol a kialakult fertőzés még visszafordítható. Itt van jelentősége az - akár ismételt - tenyésztéseknek, amelyek megteremtik a célzott kezelés alapját.

Bizonyított, hogy az immunszuppresszió és a sebészi beavatkozás egyaránt csökkenti az immunrendszer aktivitását. Számos országban a HCV-fertőzés okozta cirrhosis a májtranszplantáció egyik leggyakoribb indikációja. Micheloud és mtsai szerint a mútét után közvetlenül kiújuló HCV-fertőzés nem specifikus választ hoz létre. A HCV a CD19+ B-sejtekbe jutva módosítja a sejtek proliferációját, illetve gátolja az apoptózist. A szerzők hangsúlyozzák, hogy HCV-fertőzés esetén nagyobb az esély a társfertőzés kialakulására [28].

\section{Posztoperatín idöszak és fertözések}

Bart van Hoek és mtsai a májátültetést követő infekciók gyakoriságát vizsgálták a leideni egyetemen: a fertőzések közül - saját eredményeinkhez hasonlóan - a bakteriális eredetű infekciók voltak a leggyakoribbak (72\%), ezt követte a virális $(20 \%)$ és a fungális $(8 \%)$ fertőzés. A szerző is kihangsúlyozza az alig észrevehető, esetenként hiányzó tüneteket [29].

Saját anyagunkban az eredmények azt mutatják, hogy a tüdő és légutak gyakran képezték fertőzés forrását azoknál a betegeknél, ahol pozitív tenyésztési leletet regisztráltunk (például BAL). A folyamatosan fejlődő mütéti technika, antimikrobiális profilaxis, immunszuppresszió, anesztézia és intenzív osztályos ellátás ellenére a májtranszplantált betegek körében gyakrabban alakult ki pulmonalis szövődmény Feltracco és mtsai közlése szerint is [30]. A pulmonalis infekció fóbb rizikófaktorai a következők: a recipiens életkora, a májelégtelenség súlyossági foka, akut veseelégtelenség, dohányzás, emphysema, magas szisztolés pulmonalis artériás nyomás, hypoxia, hepatopulmonalis szindróma, politranszfúzió talaján kialakult ARDS, a rekesz iatrogén sérülése hepatectomia során vagy átmeneti rekeszizom-paresis [30]. A krónikus májelégtelenségben szenvedő betegek egy részénél a tüdő keringésében hemodinamikai zavar alakul ki: lokálisan, az alveolaris-artériás oxigéntenziók közti jelentős különbséggel, gyengébb vascularis tónussal; illetve csökken a hypoxiára adott pulmonalis vasoconstrictor válasz [30]. Azoknál a recipienseknél, akik magas MELD-értékkel kerülnek májtranszplantációra, nagyobb eséllyel alakul ki pleuralis folyadékgyülem, folyadékretenció, restriktív légzési elégtelenség, illetve izomatrophia (a csökkent nutricionális státus miatt), és nagyobb mennyiségü transzfúzióra van szükségük [30]. Huang és mtsai szerint a pulmonalis fertőzésre prediszponáló tényezők: a preoperatív légzéstámogatás, a csökkent vesefunkció, a diabetes mellitus és maga az operáció [31]. Az endotrachealis tubus használata bizonyítottan hajlamosít fertőzés kialakulására, ugyanis sérül a mucocutan védőbarrier. A post-OLT fellépő pneumonia klinikai jelei között ugyanúgy szerepel a láz, a leukocytosis, a pulmonalis infiltrátum, az újonnan fellépő légzési tünetek - köhögés, köpet és dyspnoe -, mint az átlagos betegeknél. Az utóbbi években számos közlemény jelent meg a post-OLT pneumonia incidenciájával és mortalitásával kapcsolatban. Pirat és mtsai tanulmányában májátültetést követően a betegek 22,7\%-ában alakult ki pneumonia, és ez 40\%-os mortalitási adatokkal társult [32]. A bakteriális pneumonia incidenciája a posztoperatív 6 . napon a legmagasabb, míg a 8-9. naptól csökkenés figyelhető meg [30]. A kórkép összefüggésbe hozható az elhúzódó mechanikus légzéstámogatással, az elhúzódó intenzív osztályos kezeléssel, tracheostoma kialakításával, a primer graft elégtelenségével és a vesepótló kezeléssel [30]. 
A májátültetést követően kialakuló pulmonalis eredetű fertőzésekre való hajlam összetett. Egyrészt, a mútét alatti - esetlegesen - nagy vérveszteség nemcsak a vesét károsítja, hanem ARDS megjelenésével is összefügg. Másrészt, a rekeszizmot is érintő hepatectomia (mivel a zsugormáj eltávolítása sokszor rekeszsérüléssel jár) átmeneti rekeszbénulást és pleuralis folyadékgyülemet okozhat. Továbbá a tüdő érzékennyé válik a kisvérköri pangás miatt: a crossclamp alatt ugyanis a VCI le van fogva, és csökken a jobb pitvar preloadja. Ráadásul, a májcirrhosisban gyakran előforduló HPS a kórfolyamatot tovább rontja. A betegek korai mobilizálása, a légzőtorna, szükség esetén invazív légút tisztítás/leszívás (BAL) segít a posztoperatív pneumoniák megelőzésében. A korai poszttranszplantációs időszakban kialakult pulmonalis fertőzésekre a Gram-negatív patogének jellemzőek. A kórokozók, amelyek gyakran kolonizálják az oropharyngealis területet, felelősek az alsó légúti fertőzésért. Jellemző nosocomialis patogének a P. aeruginosa, az E. coli, Klebsiella spp., Acinetobacter spp. és a $S$. aureus. Ezek a baktériumok gyakran kimutathatók a BAL-mintából. A tenyésztések 61,5\%-a Gram-negatív, 38,5\%-a Grampozitív kórokozó volt Weiss és mtsai kutatásában [33].

Saját eredményeink alapján PNF és IPF mellett és után gyakrabban fordult elő fertőzés, továbbá gyakran követte fertőzés kialakulása a hasűri vérzés miatti reoperációkat is. Bart van Hoek és mtsai szerint az IPF kialakulása mellett fokozott a kockázata a bakteriális fertőzésnek [29]. Borzio és mtsai cirrhoticus betegeket vizsgálva azt tapasztalták, hogy a hasûri vérzés prediszponáló faktor a bakteriális infekciók kialakulására [34]. Az ismételt mütéti beavatkozás (reoperációk) során óhatatlanul bevitt kórokozók a hasüregi haematoma és az esetlegesen kialakuló átmeneti graftischaemia (diszlokációs, kompressziós tünetek) ugyanis kiváló táptalajként szolgálnak. Ezt tovább erôsíti a bakteriális kolonizáció miatt az intestinalis mucosa megnőtt permeabilitása, illetve a keringésbe jutó endotoxinok károsító hatása [34].

A sebfertőzés és a periallograft-infekció a szervtranszplantáció egyik lehetséges szövődménye [35]. Saját anyagunkban nem találtunk szignifikáns összefüggést a fertőzések kialakulása és az akut rejekció (és annak kezeléseként alkalmazott szteroid-lökésterápia) előfordulása között. Érdekes azonban, hogy az irodalomban fordított irányú ok-okozati összefüggés is felmerül az akut rejekció és a fertőzések kialakulása között. Abmed és mtsai szerint a bakteriális fertőzés alloreaktivitást indukál, emiatt beindul a természetes immunválasz, ez pedig akut rejekciót eredményez [36]. Ebben a folyamatban a természetes immunválasz számos eleme részt vesz, mint a patogén mintázatot felismerő receptorok (PRRs) vagy a proinflammatorikus citokinek. Az alloreaktivitás hátterében a bakteriális antigén és az allospecifikus T-sejt-válasz közötti molekuláris keresztreakció áll [36].

Vizsgálataink során azt tapasztaltuk, hogy a fertőzések másik jelentős része epeúti eredetű, azaz cholangitis. A részleges epeúti ischaemia következménye lehet a bak- térium okozta cholangitis és tályog. A cholangitis kialakulásában szerepet játszik az anastomosis kialakításának módja. Például choledocho-jejunostomosis esetén gyakrabban észleltek infekciót [28], elsősorban az aszcendáló fertőzés - a Vater-papilla hiánya - miatt. Az epeúti szövődmények az esetek többségében cholangitisszel is együtt járnak, és az infektív góc általában Gram-negatív kórokozót és egy idő után gombát is tartalmaz. Ezért az epeúti szövődményeket mihamarabb orvosolni kell, a korai szakban mútéttel (reoperáció, reanastomosis, hepaticojejunostomia), ha ez nem lehetséges, akkor intervencióval (PTD, stent). A tenyésztés azonban minden esetben elvégzendő. Thomas Starzl és mtsai szerint az epeútrendszer a májtranszplantáció Achilles-sarka [37].

Saját összefoglaló közleményünkben részletesen elemezzük a májátültetés utáni epeúti szövődményeket. Ezek kialakulása számos okkal magyarázható, amelyek lehetnek technikai eredetűek. A beültetésnél vétett technikai hibák egy része mérhető és kvantifikálható a DorosNemes-score használatával [38]. Az okok más része a donor-hepatectomiával függ össze, ismét más részük magával az epében kialakuló epesav-összetétellel [39].

A bacteriobilia cholangitishez és biliaris szepszishez vezethet. Kawecki vizsgálatában a leggyakoribb kórokozók a következők voltak: E. coli, Klebsiella-, Enterococcus- és Pseudomonas-fajok, anaerob baktériumok. Közlése szerint a cholangitis 33\%-os mortalitással járt [40]. Kawecki és mtsai vizsgálata alapján az epeúti fertőzések hátterében többségében ugyan KNS volt kimutatható, kérdés azonban kórokozó szerepe [40]. Gotthardt és mtsai kutatásában 213 májtranszplantált beteg szerepelt, akiket a posztoperatív időszakban endoszkópos retrográd cholangiográfiával (ERCP) vizsgáltak [41]. Az epemintákból 57\%-ban Gram-pozitív, 24\%-ban Gram-negatív baktérium, 19\%-ban gomba tenyészett ki [41]. A cholangitis klinikai jelei tapasztalhatóak voltak, azonban a gyulladás laboratóriumi jelei hiányoztak. A szerzők nem találtak összefüggést a multirezisztens törzsek előfordulása és a klinikai, illetve laboratóriumi tünetek között. Megállapításuk szerint az epeúti fertőzéseket okozó bakteriális spektrum hatással van a betegek túlélésére [41].

Emori és mtsai közlése alapján a nosocomialis fertőzések további gyakori oka a sebészi infekció és véráramfertőzések voltak. Az operációt követő hónapban a bakteriális infekciók domináltak. A bacteriaemia leggyakoribb locusai a hasi és intravascularis katéterek, de nem ritka, hogy nem sikerül a forrást azonosítani [42]. Kirby és mtsai szoros összefüggést találtak a korai poszttranszplantációs időszakban bekövetkező halálozás és a bacteriaemia előfordulása között [43]. Ugyanakkor Kawecki és $m$ tsai korábbi vizsgálatukban ezt nem tudták megerősíteni [9]. A bacteriuria legfóbb prediszponáló tényezője a hólyagkatéter tartós használata [41]. Egy varsói tanulmány szerint a transzplantáltak $80 \%$-a kap húgyúti fertőzést az első évben. Az uroinfekciót okozó baktériumok többségében Gram-negatív kórokozók, ezen belül a leg- 
magasabb százalékban az E. coli azonosítható [44]. Az Egyesült Államokban is hasonló eredményeket publikáltak. Érdekes, hogy dán vizsgálatok több Gram-pozitív fertőzést mutattak ki, mint Gram-negatívat. Az uropatogén baktériumok között nagyobb mértékben fordul elő antibiotikum-rezisztencia, amelynek oka az MDR-törzsek gyors megjelenése, a hatástalan kezelés és a reinfekció [45].

\section{Saját vizsgálataink}

A mintavétel során előforduló kórokozókat részletesen is vizsgáltuk. A mikrobák esetén érthető, hogy a T+I+ csoportban a gombák, a kevert fertőzések és a Gram-negatív kórokozók voltak elötérben, például C. albicans, $P$. aeruginosa, $K$. pneumoniae. Ezért lényeges, hogy a preoperatíve vagy intraoperatíve felismert rizikófaktorok esetén az antibiotikus profilaxist ki kell egészíteni az antifungalis szerekre. Ilyen rizikófaktor lehet az életkor, a magas Child/MELD score, a HRS, a mútét során észlelt nagy vérveszteség, illetve az IPF vagy korai epeúti szivárgás, esetleg reoperáció. A fungális infekciók 5-42\%-ban jellemzőek a poszttranszplantációs időszakra [46]. Jellemző a candidiasis magas előfordulási gyakorisága (60$80 \%)$, amelynek a mortalitási rátája elérheti az 50\%-ot. $\mathrm{Az}$ antifungális terápia a magas rizikófaktorral rendelkező betegeknél javasolt. Ezt megerősíti az ESCMID 2012-es ajánlása is a gombafertőzések kezeléséról (ESCMID and ECMM guidelines for the management of rare and emerging fungal infections. Clin. Microbiol. Infect. 2014, Vol. 20, Suppl. 3, és https://www.escmid.org/ escmid_library/medical_guidelines/escmid_guidelines/).

Sun és mtsai feltételezik, hogy az invazív fungális infekció megjelenésében a kialakult veseelégtelenség, kortikoszteroid alkalmazása, illetve a retranszplantáció a legjelentősebb rizikótényezók. Ebben az esetben számos centrum az amphotericin B lipidkomplexet, illetve a micafungint ajánlja [46]. Amennyiben a betegek nem kapnak antifungális profilaxist, 36-50\%-os az invazív candidiasis kialakulásának esélye [46]. Agopian és mtsai a per os fluconazolt javasolják, magas rizikó esetén pedig a voriconazolt [26].

Vizsgálatainkból kiderült, hogy összességében a kitenyészett kórokozók közül leggyakrabban a koaguláznegatín Staphylococcus (KNS; N = 108) fordult elő. A koaguláznegatív Staphylococcus a normális bőrflórán és a nyálkahártyán található. Patogén szerepét - föként a nosocomialis fertőzéseknél - 2000-ben Mandell és mtsai fedezték fel. A baktérium jellemzően hosszan tartó centrális vénás katéterek használatakor, parenteralis táplálás, antibiotikum-profilaxis, társbetegségek és egyéb prediszponáló tényező́k fennállása esetén okoz fertőzést. Számos centrum a methicillinrezisztens Staphylococcus-infekciók növekedésérôl számol be $[47,48]$. Jellemző a kialakult rezisztencia a széles körben alkalmazott antibiotikumokkal szemben. A multirezisztens KNS megtapad az orvosi eszközök felszínén, majd a sejt által szekretált nyákon keresztül jut a felszínre. A mukopoliszacharid struktúrájának köszönhetően könnyen kolonizál és szóródik kórházi környezetben. Egyik fontos virulenciafaktora a nyák, amely védelmet nyújt az antibiotikumokkal, a kemotaxissal és a fagocitózisal szemben. Mandell és mtsai a KNS-fertőzések 67,5\%-ánál találtak methicillinrezisztenciát. A KNS a nosocomialis bacteriaemia, illetve septicaemia egyik legfontosabb kórokozója - fóként immundeficientia és malignitás esetén - a morbiditást és a mortalitást jelentősen befolyásolva. Saját anyagunkban jellemzően a T+/I- csoportban észleltük, tehát elsősorban kolonizáció vagy kontamináció volt.

A Staphylococcus aureus a második leggyakrabban elöforduló baktérium a májtranszplantáció utáni tenyésztések során. A vizsgált időszakban 66 esetben találtunk baktériumtelepeket a mintavételt követóen. A $S$. aureus okozta bacteriaemia prediszponáló tényezője az intravascularis katéterek alkalmazása. Szisztémás fertőzés esetén a klinikai tünetek és a diagnózist megerősítendő kísérő jelenségek hiányozhatnak. Lokalizált infekció esetén a bacteriaemia az időben megkezdett hatásos antibiotikum-terápiával megelőzhető [49]. Az infekció szövődménye lehet a szeptikus thrombosis, endocarditis.

Saját vizsgálatunkban az Enterococcus faecalis 39 esetben tenyészett ki. A vancomycinrezisztens enterococcus prevalenciája emelkedik Európában, azonban regionális különbség tapasztalható [48]. Magas a prevalencia például Görögországban, Portugáliában és az Egyesült Királyságban. A tartósan hospitalizált betegek emésztőrendszerét a kórokozó kolonizálni képes. Ez a képesség döntően a kifejlődött rezisztenciának köszönhető [48]. Az E. faecalis a gastrointestinalis traktusban rezervoárként múködik, és fontos szerepet játszik a széles körú antibiotikumrezisztencia kialakulásában [48]. Vizsgálatunkban a kórokozó gyakrabban fordult elő kolonizáció formájában, és az esetek mindössze felében alakult ki fertőzés.

Kiemelendő patogén a Pseudomonas aeruginosa és a Klebsiella pneumoniae jelenléte is. A nosocomialis pneumonia gyakori szövődménye az elhúzódó gépi lélegeztetés, különösen a 48 órát meghaladó mechanikus légzéstámogatás. Ennek oka az oropharyngealis mikroorganizmusok aspirációja a distalis bronchusokba, de előfordul a katéterhasználattal összefüggő vérárammal való terjedés is [50]. A P. aeruginosa egy nem fermentáló, Gram-negatív opportunista patogén. Húgyúti, gastrointestinalis és légúti fertózéseket, illetve keratitist, otitis mediát és bacteriaemiát okozhat. A $P$. aeruginosa kiemelkedő szerepet játszik a kórházi fertőzésekben. Ez a mindenütt jelen lévő organizmus mind aerob, mind anaerob feltételek mellett tenyészik. A baktérium számos antimikrobiális szerrel szemben rezisztens, egy külső membránbarriernek, a multidrug efflux transzportereknek és az endogén antimikrobiális inaktivációnak köszönhetóen. A számtalan pseudomonasellenes szer fejlesztésének ellenére hamar alakul ki rezisztencia, kromoszómamutációk és géntranszfer útján. 
Hazai adatok alapján a $P$. aureginosa és a Klebsiella pneumoniae nagyobb arányban volt megtalálható a $\mathrm{T}+\mathrm{I}+$ csoportban, mint a $\mathrm{T}+/ \mathrm{I}-$ csoportban, tehát gyakran okozott klinikai fertőzést. A K. pneumoniae egy, a pneumoniák, húgyúti és az intestinalis fertőzések jelentős részéért felelős humán nosocomialis patogén. Siu és mtsai a $K$. pneumoniae-asszociált májtályog egyre nagyobb számban való kialakulásáról számolnak be [51]. A fertőzés szövődményei a következők: bacteriaemia, meningitis, endophthalmitis, nekrotizáló fasciitis [51]. Virulenciafaktorai közül kiemelendő a kolonizáció hipermukoviszkozitása és a $\operatorname{mag} A, \operatorname{rmp} A$ gének jelenléte. Kang és mtsai szerint a K. pneumoniae okozta fertözésekre való hajlam hátterében - a malignus kórképek és a diabetes mellitus mellett - a krónikus májelégtelenség áll [52].

A megnövekedett rezisztenciának köszönhetően az Escherichia coli, illetve egyéb Enterobacteriaceae által előidézett fertőzések váltak dominánssá. Az Enterobacteriaceae bontóenzimeiért felelős gének jelenlétét gyakran kísérik más antibiotikum-csoporttal szembeni csökkent ellenálló képesség. Ezek a fajok általánosságban rosszul türik a kiszáradást, a hosszú élettartamhoz a nedvességet és a nyirkosságot igénylik. Ennek ellenére a legújabb tanulmányok szerint az E. coli és a Klebsiella spp. több mint egy évet is túlél száraz környezetben [53]. Emiatt a baktériumok felszínen való túlélésében a kórház meghatározó rezervoárként van jelen [25]. A biofilmképző fajok esetén nagyobb eséllyel alakul ki rezisztencia, valamint a klórral és egyéb fertőtlenítőkkel szembeni tolerancia. Jelenleg nincs elfogadott módszer a dekolonizációra.

A peritonitis a peritoneumnak mint szervnek a lokalizált reakciója, illetve a mikroorganizmusok és azok toxinja ellen kialakult szisztémás gyulladásos válasza [54]. Három megjelenési formáját lehet megkülönböztetni. A primer bakteriális peritonitis esetén az anatómiai barrier nem szakad meg, a peritonealis infekciót általában Gram-negatív Enterobacteriaceae és Streptococcus spp. okozza. Gyakrabban fordul elő cirrhosisban és immundeficientiában szenvedő betegeknél. A szekunder forma hátterében bélfal-perforáció, intestinalis anastomosisszakadás, ischaemiás nekrózis, illetve az emésztőrendszer egyéb sérülése áll, amelynek köszönhetően a baktériumok a peritonealis térbe jutnak. Ezek a polimikrobás fertőzések döntően iatrogén és nosocomialis infekciók. A tercier peritonitis - a szekunderhez hasonlóan - polimikrobás eredetű, de a törzsek többsége rezisztens. Gyakran társbetegségek esetén és csökkent immunitású betegeknél fordul elő. Herzog és mtsai hangsúlyozzák a rizikótényezők szerepét az MDR-fertőzések kialakulásában. A hosszabb pre- és posztoperatív hospitalizáció, iatrogén peritonitis, antibiotikum-terápia megválasztása és megváltozása mind befolyásoló tényező a rezisztencia kialakulásában [54].

A hazai eredmények alapján megállapítható, hogy a T+I+ csoportba tartozó, invazív fertőzést okozó baktéri- umok a következők: KNS, S. aureus, E. coli, E. faecalis és K. pneumoniae.

A multidrug-rezisztencia vizsgálata kutatásunk egyik célkitüzése volt. Sir Alexander Fleming 1928-ban fedezte fel az első antibiotikumot. A penicillint a Penicillium notatum gombából nyerte ki. Felfedezéséért 1945-ben orvosi Nobel-díjban részesült. Az 1940-es években megkezdődött a szer klinikai felhasználása is. Ezt követően 1941-ben Abraham és Chain izolálta elsőként a penicillinázt E. coli törzsekből. 1961-ben Barber közli az MRSA jelenlétét [55]. A '80-as évek elején - számos rezisztens törzs észlelése után - megjelentek az ESBL-t termelő Gram-negatív baktériumok. A '80-'90-es években az antibiotikumokkal szembeni rezisztencia növekedésével különböző új, hatékony szer került forgalomba. Számos infekció empirikus kezelésében széles spektrumú antibiotikumot használtak. Napjainkban az orvostudomány egyre nagyobb kihívással néz szembe: a kezelhetetlen vagy az igen nehezen kezelhető Gram-negatív infekciókkal - a kialakult rezisztenciának „köszönhetően”. Hanberger és mtsai szerint az MDR megakadályozásának egyetlen módja az infekciókontroll javítása, illetve a helyes antibiotikum-választás [56]. A rezisztencia miatt kialakuló egészségügyi költségek nagyon magasak. Az elmúlt évtizedben komoly terápiás problémát jelent az MDR Pseudomonas aeruginosa és a quinolonrezisztens E. coli. Ennek ellenére csökkent az újonnan kifejlesztett antimikrobiális szerek kutatása. A legfontosabb patogének - amelyekkel szemben fokozott a rezisztencia kialakulásának kockázata, főként immunszuppresszált betegek esetében - az Enterococcusok, S. aureus, a Klebsiella speciesek, Acinetobacter baumannii, Pseudomonas aeruginosa és az Enterobacter-fajok [57].

Korábban a gyógyszerfejlesztések döntő többsége a Gram-pozitív kórokozókat célozta meg, emiatt kevés hatékony szer volt a rezisztens Gram-negatív törzsek ellen. Az elmúlt öt évben elsődlegesen a Gram-negatív baktériumok ellen aktív antibiotikumok jelentek meg. Erre példa az ertapenem, doripenem (amelyet visszavontak), és a tigecyclin, amely egyúttal Gram-pozitív törzsek ellen is hatékony. Számos új széles spektrumú $\beta$-laktamázinhibitor áll korai klinikai fejlesztés alatt, amelyek kombinációkban kerülhetnek alkalmazásra a jövőben. Kutatás folyik az effluxpumpa-inhibitorok, monoklonális antitestek, szelektíven célzott antimikrobiális peptidek, nanoemulziók és a riboszomális kapcsolatokat célzó szerek irányában. Az MDR P. aeruginosa az Egyesült Államok kórházainak intenzív osztályain a fertőzéses esetek $20 \%$ át teszi ki [57]. Az MDR $P$. aeruginosa pneumoniát, majd fatális kimenetelú szepszist okozhat. Az intenzív kutatások ellenére a baktériumrezisztencia-hatás oka mind ez idáig ismeretlen. 1988-ban, Japánban közölték elsőként, hogy a $P$. aeruginosa törzsek metallo- $\beta$ laktamázt (MBL) termelnek. Az aztreonamot kombinációban adva a baktérium növekedését hatékonyan tudták gátolni. 
Az Enterobacteriaceae család, Acinetobacter, Pseudomonas, Stenotrophomonas és Burkholderia a kórházban szerzett fertőzések jelentős részét képezik, beleértve a pneumoniát, a vérárami és húgyúti infekciókat [58]. A rezisztens $P$. aeruginosa törzsek által okozott fertőzések nagymértékű mortalitással járnak, és jelentős szerepük van a kórházi bentfekvések időtartamának, illetve az egészségügyi költségek növekedésében. Nakamura összefüggést talált a carbapenem (például meropenem) alkalmazása és az MDR-pozitív $P$. aeruginosa megjelenése között. Ezenkívül a fluoroquinolon használata is kockázati tényezőnek bizonyult. A szerző szerint az antimikrobiális kezelések korlátozásával - ami az imipenem és ceftazidim csökkentett használatát is jelenti - a két szerre rezisztens baktériumok előfordulási aránya figyelemre méltó csökkenést mutatott. A kórokozó megtelepedésének és elszaporodásának rizikófaktorai az említett gyógyszerek használata mellett szintén a gépi lélegeztetés, intenzív osztályon való bentfekvés, a kórházi tartózkodás hossza, sebészeti beavatkozás, továbbá a diabetes mellitus.

A hazai adatok alapján megállapítható, hogy a multidrug-rezisztencia előfordulási aránya magas, hiszen a kitenyészett baktériumok 56\%-ánál találtunk multidrugrezisztenciát. Ez összesen 107 esetet jelentett, tehát a fertőzést nem okozó, T+I- csoportban is jelen volt. Az MDR-kórokozók által okozott fertőzés - a jellegzetes tünetek, illetve az effektív korai diagnosztikus módszerek hiányában - magas morbiditással és mortalitással jár [24]. A nemzetközi irodalom szerint az MDR-kórokozók által okozott fertőzések kialakulásával összefügg a profilaktikus antibiotikum alkalmazása, a transzfúzió mennyisége és az immunszuppressziós kezelés. A multidrug-rezisztens (MDR) kórokozók száma és előfordulása az egyre szélesebb körben és spektrumban alkalmazott antibiotikumok mellett növekszik. A májátültetés után észlelt MDR-előfordulásról számos közlemény jelent meg $[8,17]$. Jelentősége, hogy MDR esetén az antibiotikus terápia lehetôségei erősen korlátozottak, és immunszuppresszió mellett a banális - az átlagos populációban - csak enyhe klinikai tüneteket okozó kórokozók is súlyos betegséget okozhatnak. Emellett az egyes baktériumfajok esetén a morbiditás és mortalitás jelentősen magasabb, illetve hosszabb idejű kórházi ápolási időt és magasabb egészségügyi költségeket eredményez. Lin Zhong és mtsai azt tapasztalták, hogy az MDR-infekciók incidenciája magasabb a transzplantált betegek körében, mint az általános sebészeti beavatkozáson átesett betegeknél. A gyermek-intenzívosztályon előforduló MDRfertőzések száma is kisebb arányú, mint a májtranszplantált betegek esetén [59].

Az MDR-baktériumok regionális különbségeket mutatnak. Például Indiában az ESBL-t termelő E. coli (extended-spectrum $\beta$-lactamase) a sebészi infekciók 79\%ánál mutatható ki. Ez a szám Új-Zélandon $5 \%$ alatt van. Az Egyesült Államokban az MRSA prevalenciája igen magas (34\%), szemben Hollandiával (<2\%) [60]. Az eltérések oka a különböző antibiotikus protokollok.
A szerzettrezisztencia-mechanizmusok, mint az ESBL vagy az MRSA triggere a nagy mennyiségú antibiotikum adása. A korábban kevesebb MDR-pozitivitást mutató baktériumok, mint például az Acinetobacter baumannii - a széles spektrumú szereknek köszönhetően - megnövekedett száma tapasztalható. Nemeth és mtsai cikkükben a leggyakoribb forrásként a bőrt és a légzőrendszeri szekrétumot találták [60]. Megközelítőleg évente 18000 haláleset köthető az MDR E. coli, Klebsiella és $P$. aeruginosa okozta megbetegedésekhez az Európai Unió országaiban. Az invazív E. coli törzsek esetén például a harmadik generációs cephalosporinokkal szembeni rezisztencia emelkedett, 2002-től 2009-ig tartó vizsgálat szerint 1,7\%-ról 8\%-ra. Ennél még jelentősebb probléma a carbapenemázt termelő Enterobacteriaceae törzsek elterjedése. Jellemzően korezisztensek: a legtöbb antibiotikum hatástalan, csekély kezelési lehetőséget adva. Az Egyesült Királyságban az elmúlt években a nosocomialis fertőzések prevenciójára és a megelőzés szabályozására fektettek hangsúlyt. Khan és mtsai szerint ezeknek az egészségügyi intézkedéseknek köszönhető az MRSA okozta véráramfertőzések csökkenése [53]. Snyder és mtsai szerint az MDRGN (multidrug-resistant gram negative bacteria) okozta fertőzésekhez jelentős morbiditási és mortalitási eredmény köthető, ezek gyakorisága egyre nó [61]. Klinikailag manifeszt infekció esetén $(\mathrm{T}+\mathrm{I}+)$ a kumulatív betegtúlélésben nem volt szignifikáns túlélési különbség az MDR+vs. MDR- csoport között: az egyéves betegtúlélés 70,2\% és 70,5\% volt a két csoportban.

\section{Következtetések}

A Transzplantációs és Sebészeti Klinikán májátültetett betegek adatainak vizsgálata során, retrospektív vizsgálat keretében, arra kerestünk választ, hogy milyen összefüggések vannak a májtranszplantációt követő tenyésztések (ezen belül bakteriális kolonizációk és valós patogének), illetve az infekciók és az egyéb szövődmények, valamint a közép-hosszú távú eredmények között. Csoportokat alkottunk a tenyésztések eredményei és a regisztrált fertőzések alapján ( $\mathrm{T}+\mathrm{I}+, \mathrm{T}+\mathrm{I}-, \mathrm{T}-\mathrm{I}+)$. A vizsgált időszakban májtranszplantált betegek körülbelül $40 \%$-ánál alakult ki valamilyen klinikai tünetekkel járó mikrobás fertőzés. A szokásos és az irodalomban is közölt rizikófaktorok a hazai betegek között is azonosíthatóak a posztoperatív mikrobás fertőzés kialakulásakor. Ilyenek a politranszfúzió, a magasabb MELD-pontszám és a HRS. Ezek megléte esetén nagyobb a posztoperatív fertőzés kialakulásának esélye. Többször tapasztaltuk, hogy TACés MMF-kezelésben részesült betegeknél a pozitív tenyésztés ellenére sem alakult ki fertőzés, tehát feltehetően csupán baktériumkolonizáció vagy mintavételi kontamináció történt. Saját eredmények alapján a pozitív tenyésztési lelet és kialakult fertőzés (tehát a valós patogének) mellett a betegek hosszabb időt töltöttek az intenzív osztályon és tartósabban szorultak gépi lélegezte- 
tésre. A kezdeti csökkent graftmúködési zavar (IPF), akut veseelégtelenség, epeúti szövődmény és hasúri vérzés mellett és után gyakrabban fordult elő posztoperatív fertőzés. Sebészi vagy radiológiai reintervenció, beleértve az epeúti reintervenciót is, szintén önálló rizikófaktor a klinikai tünetekkel járó fertőzés kialakulására. Továbbá vizsgáltuk a tenyésztések baktériumspektrumát és azok forrását. A 281 tenyésztési minta vizsgálata során a fertőzések közül a bakteriális esetek voltak a leggyakoribbak. A leggyakrabban kitenyészett kórokozók a következók voltak: koaguláznegatív Staphylococcus, Staphylococcus aureus, Enterococcus faecalis, Candida albicans, Pseudomonas aeruginosa és a Klebsiella pneumoniae. A kórokozók többsége különböző kombinációkban fordul elő. Választ vártunk arra a kérdésre, hogy az MDR milyen arányban fordul elő az általunk vizsgált csoportokban és az előfordulási gyakorisága hogyan alakult az évek során. Eredményeink alapján elmondható, hogy az elemzett tenyésztési leletek 56\%-ában volt kimutatható multidrugrezisztens kórokozó. Természetesen ezek nem mindegyikéhez kapcsolódik klinikailag aktív fertőzés. Az MDR-megjelenésben csökkenő tendencia tapasztalható a májátültetési program vizsgált tízéves időperiódusában, ami feltehetően az antibiotikus profilaxis változásának, a tudatos, célzott, antimikrobás politikának és a kevesebb felhasznált vérkészítménynek tulajdonítható. Az immunszuppresszió önmagában nem okoz fertőzést, de ha további faktorok jelentkeznek, akkor a fertőzés kialakulásának kockázata magas, illetve szúk az a terápiás terület és időintervallum, ahol a kialakult fertőzés még visszafordítható. Itt van jelentősége a tenyésztéseknek, mert a célzott kezelés alapját teremtik meg.

Vizsgálataink során azt tapasztaltuk, hogy a fertőzések egyik jelentős része cholangitis formájában jelentkezik. Az epeúti szövődmények a posztoperatív fertőzések talaját is megteremtik. Elmondható, hogy egyes technikai szövődmények, még rekonstrukció esetén is, hosszú távon kihatnak az infekciók és az MDR kialakulása területén. A mútét nehézsége, hossza, időzítése, az anatómiai variációk és a sebészi tapasztalat kombinációját számszerüsíti a Doros-Nemes-score, amely lineárisan összefügg az epeúti szövődmények incidenciájával is. Saját anyagunkban az eredmények azt mutatják, hogy a másik csoport, a pulmonalis eredetű fertőzések is gyakran képezték a fertőzés okát. Mindkét betegkörben sok volt egyúttal a valós patogéneket kimutató pozitív tenyésztési lelet. A tenyésztések elősegíthetik a diagnózis korai felállítását és a célzott antibiotikus terápia megkezdését, azonban a negatív tenyésztés nem zárja ki az infekció jelenlétét.

A májátültetés után kialakuló posztoperatív fertőzések - különösen az MDR-kórokozók jelentős előfordulása miatt - folyamatos konzultációt, csapatmunkát igényelnek. Klinikai tünetek fennállása esetén egy adott betegnél többnyire az újabb antibiotikus kezelési kombinációk ésszerû alkalmazását teheti szükségessé. A retrospektív adatok szerint, az eddigi döntések jó irányba mutattak, hiszen még klinikailag manifeszt infekció esetén sem volt szignifikáns túlélési különbség a kumulatív betegtúlélésben, az MDR+ vs. MDR- csoport között: az egyéves betegtúlélés 70,2\% és 70,5\% volt a két csoportban. Egy szervátültetési program egészének perspektívájából az infekciókontroll és ezen belül az MDR-kórokozók menedzselése sok tekintetben a preventív szemléletet, azaz logisztikai, higiéniai, izolációs elvek kialakítását és szigorú betartását, valamint mútéttechnikai, transzfúziós és egyéb kezelési stratégiák folyamatos egyeztetését és fejlesztését kell, hogy megcélozza.

Anyagi támogatás: A közlemény megírása, illetve a kapcsolódó kutatómunka anyagi támogatásban nem részesült.

Szerzői munkamegosztás: N. B.: Hipotézisek, irányvonalak kijelölése, csoportosítások, adatbevitel megszervezése, kézirat megszövegezése, véglegesítés. G. F.: Adatgyưjités, statisztikai elemzés. D. E.: Adatgyưjités, irodalomgyújtés, táblázatok szerkesztése. G. Gy.: Adatelemzés, statisztika, irodalom rendszerezése. F. I., K. L.: Adatok klinikai összefüggései. G. D.: Adatok klinikai összefüggései, bírálata. F. J.: Aneszteziológiai, intenzív terápiás szempontok értékelése. V. E.: Intenzív terápiás és infektológiai szempontok értékelése. G. Zs.: Infektológiai és mikrobiológiai szempontok értékelése. D. A.: Intervencionális radiológiai szempontok értékelése. M. Z.: Májátültetés összesítő szempontok, relevancia a hazai program szempontjából.

Érdekeltségek: A szerzőknek nincsenek érdekeltségeik.

\section{Irodalom}

[1] Starzl, T. E.: Experience in hepatic transplantation. WB Saunders, Philadelphia, 1969.

[2] Calne, R. Y., William, R.: Liver transplantations in man. I. Observations on technique and organization in five cases. Br. Med. J., 1968, 4(5630), 535-540.

[3] Adam, R., Karam, V., Delvart, V., et al.: Evolution of indications and results of liver transplantation in Europe. A report from the European Liver Transplant Registry (ELTR). J. Hepatol., 2012, $57(3), 675-688$.

[4] Nemes, B., Sárváry, E., Kóbori, L., et al.: The demographic, perioperative and mortality characteristics of the Hungarian Liver Transplant Program. [A hazai májátültetés demográfiája, perioperatív jellemzői és mortalitása.] Orv. Hetil., 2005, 146(27), 1423-1432. [Hungarian]

[5] Nemes, B., Kóbori, L., Gálffy, Z., et al.: Clinical factors in association with the complications and the outcome of liver transplantation. The Hungarian experience. [A májátültetés szövődményeit és túlélési eredményeit befolyásoló tényező́k Magyarországon.] Orv. Hetil., 2005, 146(30), 1567-1574. [Hungarian]

[6] Patonai, A., Nemes, B., Görög, D., et al.: Pathologic evaluation of orthotopic liver transplantation in Hungary. [A hazai májtranszplantációk értékelése pathologiai szempontból (összefoglaló tanulmány).] Orv. Hetil., 2001, 142(9), 435-441. [Hungarian]

[7] Alqabtani, S. A.: Update in liver transplantation. Curr. Opin. Gastroenterol., 2012, 28(3), 230-238. 
[8] Giamarellou, H.: Multidrug-resistant Gram-negative bacteria: how to treat and for how long. Int. J. Antimicrob. Agents, 2010, 36(Suppl. 2), S50-S54.

[9] Kawecki, D., Chmura, A., Pacholczyk, M., et al.: Etiological agents of bacteremia in the early period after liver transplantation. Transplant. Proc., 2007, 39(9), 2816-2821.

[10] Morata, L., Cobos-Trigueros, N., Martinez, J. A., et al.: Influence of multidrug resistance and appropriate empirical therapy on the 30-day mortality rate of Pseudomonas aeruginosa bacteremia. Antimicrob. Agents Chemother., 2012, 56(9), 4833-4837.

[11] Safdar, N., Said, A., Lucey, M. R.: The role of selective digestive decontamination for reducing infection in patients undergoing liver transplantation: a systematic review and meta-analysis. Liver Transpl., 2004, 10(7), 817-827.

[12] Levy, M. M., Fink, M. P., Marshall, J. C., et al.: 2001 SCCM/ ESICM/ACCP/ATS/SIS International Sepsis Definitions Conference. Crit. Care Med., 2003, 31(4), 1250-1256.

[13] De Smet, A. M., Kluytmans, J. A., Cooper, B. S., et al.: Decontamination of the digestive tract and oropharynx in ICU pa tients. N. Engl. J. Med., 2009, 360(1), 20-31.

[14] Karapanagiotou, A., Kydona, C., Papadopoulos, S., et al.: Infections after orthotopic liver transplantation in the intensive care unit. Transplant. Proc., 2012, 44(9), 2748-2750.

[15] United Network for Organ Sharing. Data and reports. 2011. http://www.unos.org

[16] Karvellas, C. J., McPhail, M., Pink, F., et al.: Bloodstream infec tion after elective liver transplantation is associated with increased mortality in patients with cirrhosis. J. Crit. Care, 2011, 26(5), $468-474$

[17] Zhong, L., Men, T. Y, Li, H., et al.: Multidrug-resistant gramnegative bacterial infections after liver transplantation. Spectrum and risk factors. J. Infect., 2012, 64(3), 299-310.

[18] Goldaracena, N., Méndez, P., Quiñonez, E., et al.: Liver transplantation without perioperative transfusions. Single-center experience showing better early outcome and shorter hospital stay. J. Transplant., 2013, 2013, ID 649209.

[19] Avkan-Oguz, V., Ozkardesler, S., Unek, T., et al.: Risk factors for early bacterial infections in liver transplantation. Transplant. Proc., 2013, 45(3), 993-997.

[20] Giunta, V., Ferrer, M., Esperatti, M., et al.: ICU-acquired pneumonia with or without etiologic diagnosis: a comparison of outcomes. Crit. Care Med., 2013, 41(9), 2133-2143.

[21] Safdar, N., Said, A., Lucey, M. R.: The role of selective digestive decontamination for reducing infection in patients undergoing liver transplantation: a systematic review and meta-analysis. Liver Transpl., 2004, 10(7), 817-827.

[22] Wiesner, R. H., Hermans, P. E., Rakela, J., et al.: Selective bowel decontamination to decrease gram-negative aerobic bacterial and Candida colonization and prevent infection after orthotopic liver transplantation. Transplantation, 1988, 45(3), 570-574.

[23] Leone, M., Albanese, J., Antonini, F., et al.: Long-term (6-year) effect of selective digestive decontamination on antimicrobial resistance in intensive care, multiple-trauma patients. Crit. Care Med., 2003, 31(8), 2090-2095.

[24] Benus, R. F., Harmsen, H. J., Welling, G. W., et al.: Impact of digestive and oropharyngeal decontamination on the intestinal microbiota in ICU patients. Intensive Care Med., 2010, 36(8), 1394-1402.

[25] Guet-Revillet, H., Le Monnier, A., Breton, N., et al.: Environmental contamination with extended-spectrum $\beta$-lactamases: is there any difference between Escherichia coli and Klebsiella spp? Am. J. Infect. Control., 2012, 40(9), 845-848.

[26] Agopian, V. G., Petrowsky, H., Kaldas, F. M., et al.: The evolution of liver transplantation during 3 decades: analysis of 5347 consecutive liver transplants at a single center. Ann. Surg., 2013, $258(3), 409-421$
[27] Nemes, B., Sárváry, E., Sótonyi, P., et al.: Factors in association with sepsis after liver transplantation: the Hungarian experience. Transplant. Proc., 2005, 37(5), 2227-2228.

[28] Micheloud, D., Salcedo, M., Bañares, R., et al.: High rate of infection and immune disorders in patients with hepatitis $\mathrm{C}$ virus after liver transplantation. Transpl. Infect. Dis., 2009, 11(4), 367372.

[29] van Hoek, B., de Rooij, B. J., Verspaget, H. W.: Risk factors for infection after liver transplantation. Best Pract. Res. Clin. Gastroenterol., 2012, 26(1), 61-72.

[30] Feltracco, P., Carollo, C., Barbieri, S., et al.: Early respiratory complications after liver transplantation. World J. Gastroenterol., 2013, 19(48), 9271-9281.

[31] Huang, C. T., Lin, H. C., Chang, S. C., et al.: Pre-operative risk factors predict post-operative respiratory failure after liver transplantation. PLoS ONE, 2011, 6(8), e22689.

[32] Pirat, A., Ozgur, S., Torgay, A., et al.: Risk factors for postoperative respiratory complications in adult liver transplant recipients. Transplant. Proc., 2004, 36(1), 218-220.

[33] Weiss, E., Dahmani, S., Bert, F., et al.: Early-onset pneumonia after liver transplantation: microbiological findings and therapeutic consequences. Liver Transpl., 2010, 16(10), 1178-1185.

[34] Borzio, M., Salerno, F., Piantoni, L., et al.: Bacterial infection in patients with advanced cirrhosis: a multicentre prospective study. Dig. Liver Dis., 2001, 33(1), 41-48.

[35] Kawecki, D., Chmura, A., Pacholczyk, M., et al.: Surgical site infections in liver recipients in the early posttransplantation period: etiological agents and susceptibility profiles. Transplant. Proc., 2007, 39(9), 2800-2806.

[36] Ahmed, E. B., Alegre, M. L., Chong, A. S.: Role of bacterial infections in allograft rejection. Expert Rev. Clin. Immunol., 2008, 4(2), 281-293.

[37] Putnam, C. W., Beart, R. W. Jv., Bell, R. H. Jv., et al.: Hepatic transplantation, 1975. Postgrad. Med. J., 1976, 52(Suppl. 5), 104-108.

[38] Nemes, B., Gámán, G., Doros, A.: Biliary complications after liver transplantation. Expert Rev. Gastroenterol. Hepatol., 2015, 9(4), 447-466.

[39] Op den Dries, S., Sutton, M. E., Lisman, T., et al.: Protection of bile ducts in liver transplantation: looking beyond ischemia. Transplantation, 2011, 92(4), 373-379.

[40] Kawecki, D., Chmura, A., Pacholczyk, M., et al.: Bacteria isolated from bile samples of liver recipients in the early period after transplantation: epidemiology and susceptibility of the bacterial strains. Transplant. Proc., 2007, 39(9), 2807-2811.

[41] Gotthardt, D. N., Weiss, K. H., Rupp, C., et al.: Bacteriobilia and fungibilia are associated with outcome in patients with endoscopic treatment of biliary complications after liver transplantation. Endoscopy, 2013, 45(11), 890-896.

[42] Fiore, A. E., Butler, J. C., Emori, T. G., et al.: A survey of methods used to detect nosocomial legionellosis among participants in the National Nosocomial Infections Surveillance System. Infect. Control. Hosp. Epidemiol., 1999, 20(6), 412-416.

[43] Kirby, R. M., McMaster, P., Clements, D., et al.: Orthotopic liver transplantation: postoperative complications and their management. Br. J. Surg., 1987, 74(1), 3-11.

[44] Kawecki, D., Pacholczyk, M., Eagiewska, B., et al.: Urinary tract infections in the early posttransplant period after liver transplantation: etiologic agents and their susceptibility. Transplant. Proc., 2011, 43(8), 3052-3054.

[45] Rice, J. C., Safdar, N., and AST Infectious Diseases Community of Practice: Urinary tract infections in solid organ transplant recipients. Am. J. Transplant., 2009, 9(Suppl. 4), S267-S272.

[46] Sun, H. Y., Cacciarelli, T. V., Singh, N.: Micafungin versus amphotericin B lipid complex for the prevention of invasive fungal infections in high-risk liver transplant recipients. Transplantation, 2013, 96(6), 573-578. 
[47] Winn, W. C., Allen, S. D., Janda, W. M., et al.: Koneman's color atlas and textbook of diagnostic microbiology. 6th ed. Lippincott Williams and Wilkins, Philadelphia, 2006.

[48] Palazzo, I. C., Araujo, M. L., Darini, A. L.: First report of vancomycin-resistant Staphylococci isolated from healthy carriers in Brazil. J. Clin. Microbiol., 2005, 43(1), 179-185.

[49] Hetem, D. J., de Ruiter, S. C., Buiting, A. G., et al.: Preventing Staphylococcus aureus bacteremia and sepsis in patients with Staphylococcus aureus colonization of intravascular catheters: a retrospective multicenter study and meta-analysis. Medicine (Baltimore), 2011, 90(4), 284-288.

[50] Golia, S., Srilatha, K. T., Vasudha, C. L.: Microbial profile of early and late onset ventilator associated pneumonia in the intensive care unit of a tertiary care hospital in Bangalore, India. J. Clin. Diagn. Res., 2013, 7(11), 2462-2466.

[51] Siu, L. K., Yeh, K. M., Lin, J. C., et al.: Klebsiella pneumoniae liver abscess: a new invasive syndrome. Lancet Infect. Dis., 2012, 12(11), 881-887.

[52] Kang, C. I., Kim, S. H., Bang, J. W., et al.: Community-acquired versus nosocomial Klebsiella pneumoniae bacteremia: clinical features, treatment outcomes, and clinical implication of antimicrobial resistance. J. Korean Med. Sci., 2006, 21(5), 816-822.

[53] Khan, A. S., Dancer, S. J., Humphreys, H.: Priorities in the prevention and control of multidrug-resistant Enterobacteriaceae in hospitals. J. Hosp. Infect., 2012, 82(2), 85-93.

[54] Herzog, T., Chromik, A. M., Uhl, W.: Treatment of complicated intra-abdominal infections in the era of multi-drug resistant bacteria. Eur. J. Med. Res., 2010, 15(12), 525-532.

[55] Terry Alli, O. A., Ogbolu, D. O., Mustapha, J. O., et al.: The nonassociation of Panton-Valentine leukocidin and $\operatorname{mec} A$ genes in the genome of Staphylococcus aureus from hospitals in South Western Nigeria. Indian J. Med. Microbiol., 2012, 30(2), 159164.

[56] Hanberger, H., Giske, C. G., Giamarellou, H.: When and how to cover for resistant gram-negative bacilli in severe sepsis and septic shock. Curr. Infect. Dis. Rep., 2011, 13(5), 416-425.

[57] Moellering, R. C. Jr: Advances in antibacterial therapy. Transplant. Proc., 2011, 43(6), 2441-2442.

[58] Lam, O. L., Bandara, H. M., Samaranayake, L. P., et al.: Oral health promotion interventions on oral yeast in hospitalised and medically compromised patients: a systematic review. Mycoses, 2012, 55(2), 123-142.

[59] Zhong, L., Men, T. Y., Li, H., et al.: Multidrug-resistant gramnegative bacterial infections after liver transplantation - spectrum and risk factors. J. Infect., 2012, 64(3), 299-310.

[60] Nemeth, J., Ledergerber, B., Preiswerk, B., et al.: Multidrug-resistant bacteria in travellers hospitalized abroad: prevalence, characteristics, and influence on clinical outcome. J. Hosp. Infect., $2012,82(4), 254-259$

[61] Snyder, G. M., D'Agata, E. M.: Diagnostic accuracy of surveillance cultures to detect gastrointestinal colonization with multidrug-resistant gram-negative bacteria. Am. J. Infect. Control, $2012,40(5), 474-476$.

(Nemes Balázs dr., Debrecen, Móricz Zs. krt. 22., 4032 e-mail: abnemes@hotmail.com)

\section{A rendezvények és kongresszusok híranyagának leadása}

a lap megjelenése előtt legalább 40 nappal lehetséges, a 6 hetes nyomdai átfutás miatt. Kérjük megrendelőink szíves megértését.

A híranyagokat a következő címre kérjük: Orvosi Hetilap titkársága: Budai.Edit@akkrt.hu Akadémiai Kiadó Zrt. 